\begin{abstract}
This paper is an empirical investigation into the duration of exchange rate episodes characterized by the absence of speculative attacks. We estimate a duration model for OECD countries during the 1970-1997 period. Specifically, we use semi-parametric methods to estimate model with unrestricted base-line hazards. The use of duration models allows us to account for duration dependence among the determinants of the likelihood of speculative attacks. We can test if the length of the time already spent on the peg is a determinant of the probability of exit into a currency crisis state. The results indicate, first, that increases in export growth, bank deposits growth and openness predict a decrease in the probability of exit into a currency crises state. Whereas, increases in import growth; claims on government and capital inflows in terms of portfolio investment and appreciated REER, contribute positively to the likelihood of an occurrence of a crisis. And second, the existence of a highly significant negative duration dependence. The highest probability of exit into a currency crash state is given at the initial of the peg, decreasing afterwards. This suggests the existence of a political cost of realignment that changes over the duration of the spell; growing credibility surrounding an exchange-rate-based stabilization program reduce the probability that the peg will be abandoned.
\end{abstract}

This paper was produced as part of the Centre's

Globalisation Programme 


\title{
Explaining Currency Crises: \\ A Duration Model Approach
}

\author{
MarR Mercedes Tudela
}

January 2001 
Published by

Centre for Economic Performance

London School of Economics and Political Science

Houghton Street

London WC2A 2AE

(C) MarR Mercedes Tudela, submitted May 2000

ISBN 0753014467

Individual copy price: $£ 5$ 


\title{
Explaining Currency Crises: A Duration Model Approach
}

\author{
MarR Mercedes Tudela
}

1. Introduction 1

2. Methodological Issues 5

3. Measuring Exchange Market Pressure 8

$\begin{array}{ll}\text { 4. The Data } & 14\end{array}$

5. Results 18

$\begin{array}{lll}5.1 & \text { Time-Varying Variables } & 18\end{array}$

5.2 Estimated Base-Line Hazard 24

6. Concluding Remarks 25

$\begin{array}{lll}\text { A Appendix } & 27\end{array}$

References $\quad 55$ 


\section{Acknowledgements}

MarR Mercedes Tudela is a member of the Centre for Economic Performance, London School of Economics. 


\title{
Explaining Currency Crises: A Duration Model Approach
}

\author{
María Mercedes Tudela
}

\section{Introduction}

The turbulence of the European Exchange Rate Mechanism in 1992-93, the onset of the Mexican crisis in 1994, the Asian flu in 1997 and the Russian currency markets disturbances in 1998, have renewed the interest in the potential causes of currency crises. An important part of the exchange rate literature, from both the theoretical and empirical approaches, has concentrated on the modeling of exchange rate crises ${ }^{1}$. This paper seek to explain the origins of currency crises by connecting their occurrence to the realizations of the explanatory variables. The emphasis is made on the systematic test of the power of the different variables in explaining currency crises, not in a case study of a specific devaluation episode. ${ }^{2}$

We construct for twenty OECD countries for the period 1970-97 a data set which consists of 68 spells. These spells are defined as those episodes for which a particular currency does not suffer from a speculative attack. In a broad sense we can talk of a spell as the duration of a specific peg. From here we define a tranquil state or episode as a period of time in which there is no pressure on the currency, while a crisis state is defined as a period characterized by the presence of a speculative attack, either successful or not.

We use duration analysis to study the countries' probability to leave a tranquil state exiting into a currency crisis state. The use of duration models is

\footnotetext{
${ }^{1}$ We use the terms of currency crises, speculative attack and exchange rate crises interchangeably.

${ }^{2}$ Examples of this type of studies are Blanco and Garber (1986), Jeanne and Masson (1997) and Sachs, Tornell and Velasco (1996).
} 
an innovative strategy for estimating the probabilities of exiting a currency peg. ${ }^{3}$ This method allows us not only the study of the determinants of the likelihood of a currency crash, but also the duration of the spells of tranquillity. That is, how much time countries stay in a tranquil period, how much this varies over the business cycle and how the duration of tranquil states varies across countries. ${ }^{4}$ We are looking for the determinants of the length of time a currency spends in a tranquil state. We consider that both the incidence of speculative attacks and the duration of the spells of tranquillity, are important in assessing currency stability. Exchange rate credibility cannot only depend on the event of a speculative attack, but also on the time already spent in a tranquil episode.

A duration model approach is important for our problem given the existence of non-stationarities in the real world. The characteristics of the financial markets change over time, so the probabilities of exit into a turbulent state change as well with the length of the spell. We want to capture those nonstationarities.

Including time-dependent explanatory variables in an empirical model of currency crises helps to incorporate those non-stationarities, but these models miss duration dependence as a second kind of non-stationarity. With this last feature we want to test the length of time already spent on the spell as a determinant of the likelihood of exit into a turbulent episode. We want to test if the likelihood of a devaluation is higher for tranquil periods, say, in the first quarters, than for periods that have lasted longer, after controlling for other time-varying factors. We can argue that the political costs of realignment change over the duration of the spell, maybe due to changes in the credibility of the peg. Growing credibility, surrounding an exchange-ratebased stabilization program, might reduce the probability that the peg will be abandoned. In short, we want to understand the role played by the time spent on the peg in determining the likelihood of exit into a currency crash.

Most of the empirical studies undertaken so far to estimate the probabilities of occurrence of speculative attacks are of the probit and logit nature.

\footnotetext{
${ }^{3}$ We use the expression currency peg understood as an episode of currency stability.

${ }^{4}$ These are the classical questions that Kiefer (1988) raised in his seminal paper on duration applied to unemployment data.
} 
Therefore they miss the feature of time dependence implicitly given in any currency event.

Klein and Marion (1994) suggest that even if some of the determinants for the duration of a fixed exchange-rate spell may remain constant over a spell, others will change. A simple correlation of the length of each spell with some constant measure of each explanatory variable (e.g. the value of the variable at the beginning or at the end of a spell or its change over the spell or its average value during the spell) fails to capture important information about the time path of the variable during the spell. Therefore, they claim for an empirical approach that allows to consider time-varying determinants, rejecting explicitly the use of ordinary least squares or duration analysis. They use logit models instead. ${ }^{5}$ Nevertheless, we propose more sophisticated duration models: duration models with the added feature of time-varying variables, so we do not miss the explanatory power of time-varying determinants and, moreover, we incorporate duration dependence as a second class of non-stationarity within spells.

Kumar, Moorthy and Perraudin (1998) use a logit model as well to estimate the likelihood that a country with given economic and financial characteristics, operating in a particular global environment, will have a devaluation. ${ }^{6}$ Their main concern is to develop a framework to forecast currency crises that could be useful for investors and policy makers involved in emerging markets. That is the reason to employ relatively high frequency data.

The work by Eichengreen, Rose and Wyplosz (1996) is a clear example of a systematic process of testing the predictions of theories that highlight motives for, and dynamics of, speculative attacks. They analyze a panel of quarterly macroeconomic and political data, covering twenty industrial countries from 1959 through 1993. They estimate a binary probit model linking their dependent variable (an indicator variable which takes on a value of unity for a speculative attack and zero otherwise) to their controls using maximum likelihood.

\footnotetext{
${ }^{5}$ The model is estimated for sixteen Latin American countries and Jamaica during the 1957-91 period.

${ }^{6}$ This empirical analysis is based on monthly pooled time-series cross-section data for 32 emerging markets from January 1985 to March 1998.
} 
Keeping the probabilistic approach of the above studies we estimate the probabilities of speculative attacks as realizations of a stochastic point process. But under the framework of duration or survival analysis, our interest centers on the process of movement from state (tranquil period) to state (crises period) generating a sequence of points on the time axis - the times at which transitions are made.

Each jump of the point process is the occurrence of a shock that implies the transition from a tranquil state into a crisis state. The failure time will be the length of the tranquil state.

A different approach is used in Kaminsky, Lizondo and Reinhart (1998) who examine the empirical evidence on currency crises and propose a specific early warning system. This system involves monitoring the evolution of several indicators that tend to exhibit an unusual behavior in the periods preceding a crisis. When an indicator exceeds a certain threshold value, this is interpreted as a warning signal that a currency crisis may take place within the following 24 months.

Other empirical studies concentrate only on a qualitative discussion of the causes of currency crises, stressing the evolution of one or more indicators. See for example, Dornbusch, Goldfajn and Valdés (1995), Goldstein (1996), Krugman (1996) or Milesi-Ferreti and Razin (1998).

Studying the different behavior of some key variables between the periods leading up to, and immediately following, currency crises is the aim of works by Eichengreen, Rose and Wyplosz (1995) and Moreno (1995).

The remainder of our paper is organized as follows. Section 2 concentrates on the methodological issues. Section 3 depicts the measure of speculative pressure used to analyze the empirics of speculative attacks. The data are described in Section 4. In Section 5 we present our main results. Section 6 concludes. 


\section{Methodological Issues}

We analyze the process of transition from a tranquil state to a crisis state. We define a tranquil state as a period of time in which there is no pressure on the currency. A crisis state is defined as a period characterized by the presence of a speculative attack, whether successful or not. This process generates a sequence of points on the time axis: the times at which speculative attacks occur and, therefore, the transitions are made. These movements are random, so the evolution of the state of a country over time is a realization of a stochastic point process.

Following Eichengreen et al. (1996) we do not identify currency crises with actual devaluations, revaluations and instances in which the currency is floated. The reason is twofold. First, not all speculative attacks are successful. The currency may be supported by the intervention of the national central bank via expenditure of reserves, or by foreign central banks and governments or, even, by the threat or actual imposition of capital controls. The use of interest rates and austerity policies are other alternatives to repel an attack. Second, realignments are undertaken in tranquil periods in order to preclude future attacks.

Since the monetary authority can accommodate the exchange market pressure by running down its international reserves or by raising interest rates, a measure of speculative attacks has to reflect those possibilities. For that reason, we adopt a measure of exchange market pressure inspired by the one suggested by Eichengreen et al. (1996). ${ }^{7}$

For the specification of our duration model $^{8}$ we use Cox (1972) approach of proportional hazards. With this specification, it is possible to estimate the unknown parameters without specifying the form of the base-line hazard,$^{9}$ thus providing a partially non-parametric estimator for those constants. The proportional hazard models seem a reasonable compromise between the Kaplan-Meier estimate (a non-parametric approach) and the possibly exces-

\footnotetext{
${ }^{7}$ The concrete specification of this measure is presented in the next section.

${ }^{8}$ See Kiefer (1988) and Lancaster (1990) for a discussion of these models. See as well Narendranathan and Stewart (1993) as an application of this kind of models.

${ }^{9}$ That is, the part of the hazard (the conditional probability) that is common for all individuals in a proportional hazard model.
} 
sively structured parametric models-given the absence of a theory we can follow in determining the specification of the hazard function. ${ }^{10}$

The proportional hazard specification in continuous time leads to a hazard function of the form:

$$
\lambda\left(t, x(t), \beta, \lambda_{0}\right)=\phi(x(t), \beta) \lambda_{0}(t)
$$

where $x(t)$ denotes time dependent variables, $\beta$ is a vector of unknown coefficients and $\lambda_{0}(t)$ is the base-line hazard corresponding to $\phi()=$.1 . The first component of (1), $\phi($.$) , describes the way in which \lambda$ shifts between individuals endowed with different $x^{\prime} s$ at given duration $t$. The second component, the base-line hazard, is a functional form for the dependence of $\lambda$ on duration.

A commonly used specification of $\phi$ is:

$$
\phi(x(t), \beta)=\exp \left(x(t)^{\prime} \beta\right)
$$

This specification is convenient because non-negativity of $\phi$ does not impose restrictions on $\beta$. Moreover, the vector of coefficients can be interpreted as the constant proportional effect of $x$ on the conditional probability of ending the spell. This is the analog, in a hazard setting, of the usual partial derivative interpretation of a linear regression coefficient.

In a discrete specification, the hazard function denotes the probability of moving to a crisis state in period $t+1$ conditional on being in tranquil state until period $t$. After some calculations we can write the hazard function as:

$$
h_{i}(t)=1-\exp \left\{-\exp \left(x(t)^{\prime} \beta\right)+\gamma(t)\right\}
$$

We have to express these probabilities in terms of a likelihood function to be estimated.

The contribution to log likelihood made by the $i^{\text {th }}$ observation, which fails or is censored in the $t_{j}$ interval is:

\footnotetext{
${ }^{10}$ The hazard function is a conditional probability, the probability of moving into a crises state in period $t+\Delta t$ conditional on being in a tranquil state until period $t$.
} 


$$
\begin{aligned}
L_{i}(\theta)= & d_{i} \ln \left(h_{i}(t)\right)+\sum_{t=1}^{t_{j}-1} \ln \left(1-h_{i}(t)\right) \\
= & d_{i} \ln \left\{1-\exp \left[-\exp \left(x_{i}\left(t_{j}\right)^{\prime} \beta+\gamma\left(t_{j}\right)\right)\right]\right\} \\
& -\sum_{t=1}^{t_{j}-1} \exp \left[\left(x(t)^{\prime} \beta\right)+\gamma(t)\right]
\end{aligned}
$$

where $d_{i}=1$ if the $i^{t h}$ spell is uncensored and, $d_{i}=0$ if censored. ${ }^{11}$

There still remains one more consideration about the correct likelihood function. Our data consist of $N$ countries each of which can experience multiple transitions. This is what is called multiple-cycle data. In that case, the hazard functions may depend upon the number of previous entries to the tranquil state, which is known as occurrence dependence. Or it may depend upon the lengths of previous visits to the tranquil state, which is known as lagged duration dependence. In order to write the concrete log likelihood function for a given country let us define:

$$
d_{c}=\left\{\begin{array}{l}
1 \text { if crisis state is entered at the end of the } c^{t h} \text { cycle } \\
0 \text { otherwise }
\end{array}\right\}
$$

we summarize the transition intensities, $h^{c}(t, s)$, as the hazard function for the $c^{t h}$ cycle at calendar time $t$ and elapsed duration $s$. Then, for a country which we observe over $C_{i}$ cycles, the last of which may be right censored, the log likelihood contribution will be:

$$
\begin{aligned}
L_{i}(\theta)= & \sum_{c=1}^{C_{i}}\left\{\ln \left[h_{i}^{c}\left(t_{c}^{i}, s_{c}^{i}, t_{j}\right)\right]+\sum_{t=1}^{t_{j}-1} \ln \left[1-h_{i}^{c}\left(t_{c}^{i}, s_{c}^{i}, t\right)\right]\right\} \\
& +d_{i} \ell n\left[h^{C_{i}}\left(t_{C_{i}}, s_{C_{i}}\right)\right]+\sum_{t=1}^{t_{j}-1} \ln \left[1-h^{C_{i}}\left[t_{C_{i}}, s_{C_{i}}, t\right]\right]
\end{aligned}
$$

where $h($.$) is given by (3).$

\footnotetext{
${ }^{11} \mathrm{~A}$ spell is censored when the spell is not completed: when we do not observe the whole duration of the spell until the transition to the turbulent state is made.
} 


\section{Measuring Exchange Market Pressure}

The first issue in any empirical analysis of currency crises is to define speculative attacks. We do not want to limit ourselves to successful speculative attacks, that is, to the cases in which the exchange rate regime was altered (and the currency was either defaulted or floated). Studies of this type are Milesi-Ferreti and Razin (1998) and Frankel and Rose (1996). They define currency crises based only on unusual movements of the exchange rates.

We want to capture as well those unsuccessful attacks that have been warded off by central banks and governments. The monetary authorities may accommodate the pressure on the financial markets by running down their international reserves or deter the attack by raising interest rates. In these circumstances, currency market pressures will be translated into steep increases in domestic interest rates and/or great losses of foreign exchange reserves. Therefore, a measure of speculative attacks should capture these three different forms of currency market turbulences.

In this line Eichengreen, Rose and Wyplosz (1994) construct a measure of speculative pressure by means of an index. This index is a weighted average of exchange rate changes, changes in reserves, and interest rate changes. The index of exchange market pressures is defined as:

$$
E M P_{i, t}=\alpha \Delta e_{i, t}+\beta \Delta\left(i_{i, t}-i_{t}^{*}\right)-\gamma\left(\Delta r_{i, t}-\Delta r_{t}^{*}\right)
$$

where $\alpha, \beta$ and $\gamma$ are the chosen weights, $\Delta e_{i, t}$ is the change in the exchange rate, $i_{i, t}$ denotes the domestic interest rate, $i_{t}^{*}$ corresponds to the same variable but for the country of reference, $r_{i, t}$ is the ratio of foreign reserves to domestic money for the domestic country and, $r_{t}^{*}$ denotes the same concept for the country of reference.

This is a common measure used in several studies by the same authors (Eichengreen et al. (1996), Eichengreen, Rose and Wyplosz (1997) and by Sachs et al. (1996) and Kaminsky et al. (1998), with variations in the weights given to the three components of the index.

Defining the $E M P$ index of equation 7 as an unweighted measure has the obvious advantage of the simplicity. The disadvantage is that the volatility 
of exchange rates, interests rates and reserves are very different. ${ }^{12}$ Eichengreen et al. (1994), Eichengreen et al. (1996), Eichengreen et al. (1997) and Kaminsky et al. (1998) work with the EMP index weighting the three components so as to equalize their volatilities. In this way they prevent any of the components from dominating the index.

The next step is the identification of a currency crisis using the EMP indicator. Eichengreen, Rose and Wyplosz identify quarters in which their index is at least one and a half standard deviations above the sample mean as instances of speculative attacks. To avoid counting of the same crisis more than once, they exclude the later observation when two (or more) crises occur in successive quarters.

We believe that this way of defining a currency crisis is faulty. First, the unweighted $E M P$ index is defective because it obviates the inherent different volatility of its three components. Second, the weighted EMP measure (according to the particular volatilities of its components) is inadequate because it cannot capture those episodes in which the monetary authorities were very successful in controlling a speculative attack but, however, ended with an important loss of reserves.

For these reasons we construct a third measure of speculative pressure. We use the same three indicators (exchange rate changes, changes in reserves, and interest rate changes, ${ }^{13}$ but in a rather different way. Episodes where changes in the exchange rate are superior to +1.5 standard deviations over the means are selected first as episodes of speculative attacks. From the remaining episodes we look at the reserves indicator. If changes in relative foreign reserves are below the -1.5 standard deviation band, we describe them as turbulent episodes. As new episodes of currency crisis we add those ones for which the interest rate differential is above the +1.5 standard deviation band.

\footnotetext{
${ }^{12}$ The volatility of the percentage changes in the reserves (scaled by the monetary base) is several times the conditional volatility of the percentage change in the exchange rate, which is several times the percentage in the interest differential.

${ }^{13}$ These variables are measured in relative terms with those prevailing either in Germany or in USA, depending on the country of interest. Australia, Canada, New Zealand and Japan are related to the US\$.
} 
The rest of observations are classified as periods of tranquillity. Some remarks are in order here. First, whenever we find that only one of the three variables lies outside the band, we look at the deviation from the band and the behavior of the two other variables. If the case is such that the deviation from the band is just marginal and the two other variables have a normal behavior, we disqualify that episode as a turbulent one, it is classified as tranquil. If, on the contrary, we observe that the three variables are in the margin of the band, we qualify the episode as turbulent. In order to prevent the continuation of a speculative episode from being identified as a new episode, we exclude the later observation(s) when two or more crises occur in successive quarters.

In Table A of the Appendix we report the identified turbulent episodes by the three measures. Tables B and C (see Appendix) report the official currency events and the identification of a turbulent period and the associated official event when applicable. In that way we can check for the appropriateness of our measure of speculative pressure when the attacks were successful, and the location of the unsuccessful speculative attacks.

From these tables we can conclude the superiority of our third measure over the other two. The first index, the unweighted $E M P$, identifies too few crises according to the official events. The second measure, the weighted $E M P$ (weighted in order to equalize the volatility of its three components) misses, mainly, unsuccessful speculative attacks that were faced by unusual movements in foreign reserves. A clear example is Denmark in 1992 and 1993 at the time of the tensions in the EMS. In late 1992, Denmark warded off the attacks by a huge loss in foreign reserves. This is what we call unsuccessful speculative attack and should be included in our study. An EMP index of the type of Eichengreen, Rose and Wyplosz would miss these crises since relative foreign reserves have the largest volatility (of the three components) and given that they weight the three indicators in order to equalize their volatilities, foreign reserves lose quite a lot of their importance, failing to capture this kind of crisis.

Another example along the same line is France in 1992. Using an index of the type proposed by Eichengreen, Rose and Wyplosz, we do not identify as a speculative attack episode the events of 1992 for France. Whereas, if we use our proposed measure, we do classify the episode as a speculative attack, 
given the huge loss in reserves that took place at that moment in order to prevent the crisis.

To shed some light on the characteristics of speculative pressure episodes we report the proportion of times that a change in either the exchange rate, relative foreign reserves or relative short term rates is the criterion that qualifies an episode as a period of speculative pressure. A total of $62 \%$ of turbulent episodes is explained by unusual behavior in the real exchange rate. Relative reserves identify $29 \%$ of the crises, and the rest, $9 \%$, is due to extreme movements of the short-term interest rate.

Since episodes that are classified as turbulent ones due to unusual movements in either relative reserves or relative interest rates are not accompanied by large adjustments in exchange rates (according to our measure of speculative attacks), we can say that monetary authorities have intervened actively in foreign exchange markets, using reserves and interest rates, to face speculative pressures $38 \%$ of the time. That is, monetary authorities have succeed in those occasions to prevent the large movements of the exchange rate. This is what we called unsuccessful speculative attacks.

In Figure 1 we report the distribution of the currency crises along the time axis and Table 1 shows the number of crises identified by countries. Denmark, France, Sweden and UK are the countries with the greatest number of speculative attacks. At the other extreme, Canada, Portugal, the Netherlands and Australia have the smallest number of currency crises.

Before explaining the results of our estimates, we have to report some of the characteristics of the duration of the spells. Remember that a spell is defined as the time that a particular currency does not suffer from a speculative attack, so we can talk about the duration of a specific peg in a broad sense.

Information about the duration of the pegs is provided in Table 2. Due to the lack of data, the original number of crises detected by our measure, 149, falls to 68 ( 81 spells if we consider unfinished durations) when we introduce the macro variables in our analysis (see Table 3 ).

It is assumed that one spell ends when the country leaves that state (tranquil 
Figure 1: Crises per Quarter

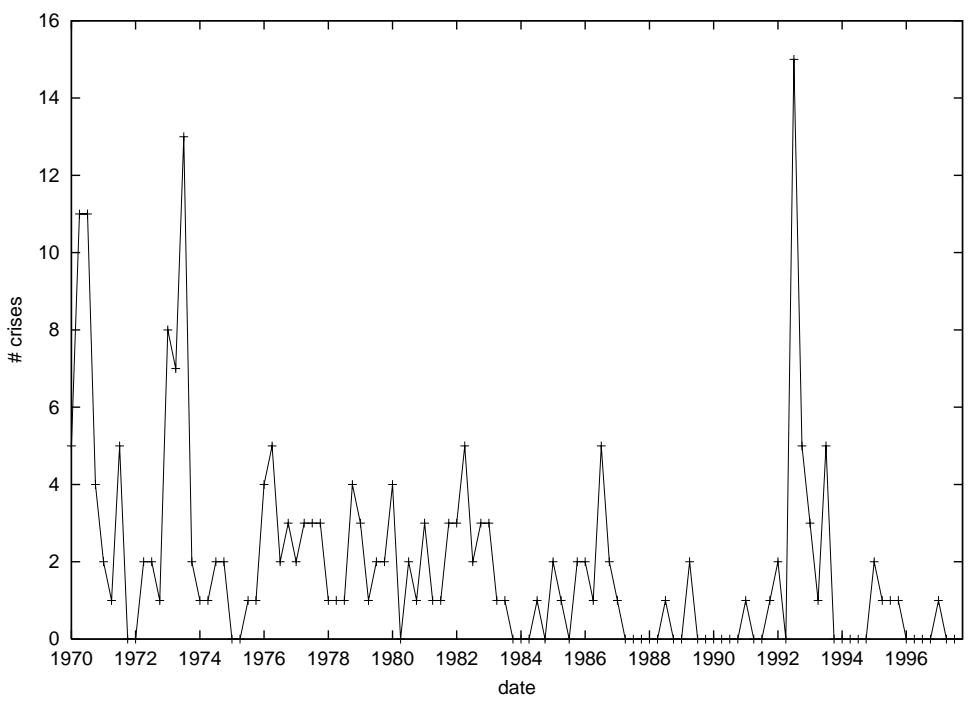

Figure 2: Duration Frequencies

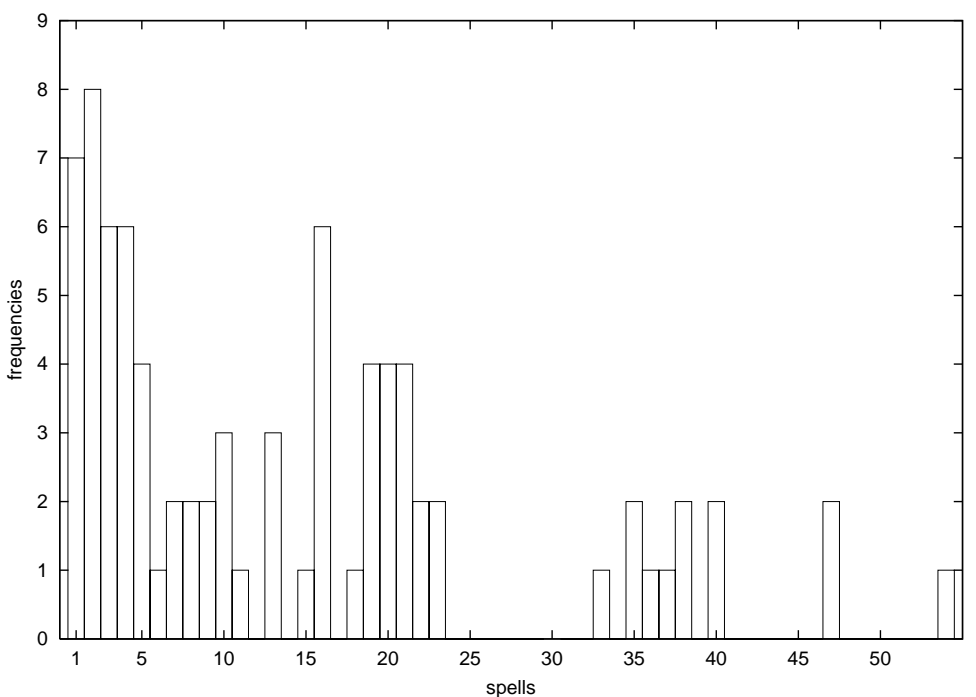


Table 1: Number of Crises by Country

\begin{tabular}{lc}
\hline \hline Country & Number of Crises \\
\hline \hline & \\
Denmark & 16 \\
France & 15 \\
Sweden & 14 \\
UK & 14 \\
Belgium & 13 \\
USA & 13 \\
Austria & 11 \\
Ireland & 11 \\
Italy & 11 \\
Norway & 11 \\
Finland & 10 \\
New Zealand & 9 \\
Switzerland & 9 \\
Greece & 9 \\
Japan & 9 \\
Spain & 9 \\
Australia & 8 \\
The Netherlands & 7 \\
Portugal & 7 \\
Canada & 5 \\
\hline mean & 10.6 \\
standard deviation & 2.9 \\
& \\
\hline \hline
\end{tabular}

${ }^{1}$ Number of total crises, we do not have excluded consecutive crises yet. 
state) to enter another one (here a currency crises state), otherwise the spell is right censored. In econometric duration models right censoring is usually modelled by a dummy variable that takes on the value 1 if an exit is observed and 0 otherwise.

From Tables 2, 3, and Figure 2, we see that the exit rate into a turbulent episode is higher in the early quarters of the peg. One third of the spells in our sample end, or are right censored in the first year of the peg, and half of them end or are right censored within two years and a half. In addition, $64 \%$ of the durations are below four years in length. According to these proportions and given the limited number of crises, we concentrate our estimates in the behavior of the base-line hazard (that is, of the duration parameters) in the four years since the beginning of the peg. This argument is reinforced for the completed spells, with $70 \%$ of the population ending spells in four years time.

\section{The Data}

We have assembled quarterly data from 1970 through 1997 for twenty OECD countries: Australia, Austria, Belgium, Canada, Denmark, Finland, France, Greece, Ireland, Italy, Japan, the Netherlands, New Zealand, Norway, Portugal, Spain, Sweden, Switzerland, the United Kingdom and the United States. The data base is the International Financial Statistics (IFS) published by the International Monetary Fund and Main Economic Indicators by OECD.

To define the indices of speculative pressure, we use data from the IFS. Here $e_{i, t}$ denotes the exchange rate in terms of national currency over DM or $\mathrm{US} \$$ of country $i$ at time $t$. We use market rates, that is the exchange rate determined largely by market forces and defined as period averages.

The discount rate, preferably, or the money market rate, depending on the availability of data, is the measure of the interest rate entering the definition of the $E M P$ index as $i_{i, t}$.

International reserves, $r_{i, t}$, are constructed as the ratio of reserves to narrow money (M1). The reserves measure excludes gold. 
Table 2: Distribution of Total Tranquil Spells

\begin{tabular}{|c|c|c|c|}
\hline $\mathrm{N}$ & Frequency & Percent & Cum. \\
\hline 1 & 7 & 8.64 & 08.64 \\
\hline 2 & 8 & 9.88 & 18.52 \\
\hline 3 & 6 & 7.41 & 25.93 \\
\hline 4 & 6 & 7.41 & 33.33 \\
\hline 5 & 4 & 4.94 & 38.27 \\
\hline 6 & 1 & 1.23 & 39.51 \\
\hline 7 & 2 & 2.47 & 41.98 \\
\hline 8 & 2 & 2.47 & 44.44 \\
\hline 9 & 2 & 2.47 & 46.91 \\
\hline 10 & 3 & 3.70 & 50.62 \\
\hline 11 & 1 & 1.23 & 51.85 \\
\hline 13 & 3 & 3.70 & 55.56 \\
\hline 15 & 1 & 1.23 & 56.79 \\
\hline 16 & 6 & 7.41 & 64.20 \\
\hline 18 & 1 & 1.23 & 65.43 \\
\hline 19 & 4 & 4.94 & 70.37 \\
\hline 20 & 4 & 4.94 & 75.31 \\
\hline 21 & 4 & 4.94 & 80.25 \\
\hline 22 & 2 & 2.47 & 82.72 \\
\hline 23 & 2 & 2.47 & 85.19 \\
\hline 33 & 1 & 1.23 & 86.42 \\
\hline 35 & 2 & 2.47 & 88.89 \\
\hline 36 & 1 & 1.23 & 90.12 \\
\hline 37 & 1 & 1.23 & 91.36 \\
\hline 38 & 2 & 2.47 & 93.83 \\
\hline 40 & 2 & 2.47 & 96.30 \\
\hline 47 & 2 & 2.47 & 98.77 \\
\hline 54 & 1 & 1.23 & 100 \\
\hline Total & 81 & & \\
\hline Mean & 14 & & \\
\hline Median & 17 & & \\
\hline Standard Deviation & 13 & & \\
\hline Range & {$[1,54]$} & & \\
\hline
\end{tabular}


Table 3: Distribution of Completed Tranquil Spells

\begin{tabular}{|c|c|c|c|}
\hline $\mathrm{N}$ & Frequency & Percent & Cum. \\
\hline 1 & 7 & 10.29 & 10.29 \\
\hline 2 & 8 & 11.76 & 22.06 \\
\hline 3 & 6 & 8.82 & 30.88 \\
\hline 4 & 6 & 8.82 & 39.71 \\
\hline 5 & 4 & 5.88 & 45.59 \\
\hline 6 & 1 & 1.47 & 47.06 \\
\hline 7 & 2 & 2.94 & 50.00 \\
\hline 8 & 2 & 2.94 & 52.94 \\
\hline 9 & 1 & 1.47 & 54.41 \\
\hline 10 & 3 & 4.41 & 58.82 \\
\hline 11 & 1 & 1.47 & 60.29 \\
\hline 13 & 3 & 4.41 & 64.71 \\
\hline 15 & 1 & 1.47 & 66.18 \\
\hline 16 & 2 & 2.94 & 69.12 \\
\hline 19 & 3 & 4.41 & 73.53 \\
\hline 21 & 4 & 5.88 & 79.41 \\
\hline 22 & 2 & 2.94 & 82.35 \\
\hline 23 & 2 & 2.94 & 85.29 \\
\hline 35 & 2 & 2.94 & 88.24 \\
\hline 36 & 1 & 1.47 & 89.71 \\
\hline 37 & 1 & 1.47 & 91.18 \\
\hline 38 & 2 & 2.94 & 94.12 \\
\hline 40 & 2 & 2.94 & 97.06 \\
\hline 47 & 1 & 1.47 & 98.53 \\
\hline 54 & 1 & 1.47 & 100 \\
\hline Total & 68 & & \\
\hline Mean & 13 & & \\
\hline Standard Deviation & 13 & & \\
\hline
\end{tabular}


We have chosen the following variables to serve as determinants of the likelihood of a speculative attack: real GDP at 1990 prices, we introduce this macroeconomic fundamental in terms of growth rates; Consumer Price Index (CPI), base year 1990, to construct the inflation indicator; unemployment, in terms of its growth rate; merchandise exports, f.o.b. and merchandise imports, c.i.f., both in terms of growth rates and defined over GDP, plus an indicator of the degree of openness of the country, constructed as exports plus imports over GDP; the real effective exchange rate index (REER), defined as a nominal effective exchange rate index adjusted for relative movements in a national cost indicator of relative normalized unit labor costs in manufacturing. The nominal effective exchange rate is an index of the period average exchange rate of the currency in question to a weighted geometric average of exchange rates for the currencies of selected countries. The weights are derived from trade in manufactured goods among industrial countries over the period 1989-91. As an indicator of the domestic monetary condition we include domestic deposits: demand deposits plus time and saving deposits. We consider again this variable deflated by GDP and in terms of rate of growth. Domestic credit, claims on government, and claims on private sector are our indicators of a possible credit expansion. To take into consideration the debate concerning capital account liberalization and the extent to which measures to increase transaction costs may alter the composition of flows, and reduce the vulnerability resulting from sudden outflows -we include in our analysis, portfolio flows and foreign direct investment (FDI).

We have to keep in mind that quarterly observations may not be a good periodicity to identify every speculative attack, especially unsuccessful ones. Pressure against pegged currencies can occur and be repelled quickly through a rise in interest rate or foreign-exchange-market intervention within the quarter. When an attack occurs and is repelled with immediate action, the average behavior of both interest rates and international reserves over the quarter are not, probably, going to reflect the intensity of speculative pressures. But the availability of data restricts us to quarterly observations in order to capture the maximum spectrum of countries in a long time period. 


\section{Results}

The results are reported in Table 4 . The dependent variable is the probability of leaving a tranquil state. The estimates for the parameters of the model are shown in the second column with their standard errors in the third column. The expected sign for the coefficients of the explanatory variables are reported in the last column.

The use of a proportional hazard model allows for an easy interpretation of the estimated parameters. If the sign is positive, the effect on the hazard rate will be positive (shorter durations). If it is negative, the effect will be negative (larger durations).

The baseline rate has been defined through a set of dummy variables, one for each quarter till the fifth. From the sixth to the eleventh it has been defined with a dummy for every two quarters. One more dummy is introduced for the next five quarters. From then on, we do not include any more dummies, since we only estimate the base-line hazard for the four first years for the reasons stated previously. The main feature of this kind of function (also known as piecewise constant hazard rate) is that it is constant in each interval, but may vary from one interval to the other. The first interval is used as the reference level.

\subsection{Time-Varying Variables}

Variables from quarter $t$ are used to determine the probability of exit in quarter $t+1$ in order to avoid feedback effects of the occurrence of a currency crash into the macroeconomic variables. ${ }^{14}$

Consider the first variable, GDP growth. The negative sign of the estimated parameter indicates that a decline in GDP growth leads to an increase in the probability of ending the spell of tranquility. That is, a weakening in economic activity is likely to be associated with an increase in the vulnerability of the currency to attacks. The underlying explanation of this result is the following: an increasing rate of growth may generate buoyancy in the

\footnotetext{
${ }^{14}$ See Agenor, Bhandari and Flood (1992), Flood and Garber (1984), Garber and Svensoon (1994), Krugman (1979) and Wyplosz (1986) for a revision of the theoretical models on currency crises.
} 
Table 4: Maximum Likelihood Estimates

\begin{tabular}{|c|c|c|c|}
\hline Parameters & Estimates & Std. error & Expected sign \\
\hline \multicolumn{4}{|l|}{ Steps } \\
\hline $\mathrm{q} 1$ & $-2.28^{* * *}$ & 0.50 & \\
\hline $\mathrm{q} 2$ & $-1.19^{* * *}$ & 0.47 & \\
\hline q3 & $-2.09^{* * *}$ & 0.38 & \\
\hline $\mathrm{q} 4$ & $-2.00^{* * *}$ & 0.50 & \\
\hline $\mathrm{q} 5$ & $-2.37^{* * *}$ & 0.56 & \\
\hline$q 6-q 7$ & $-3.39^{* * *}$ & 0.60 & \\
\hline q8-q9 & $-3.38^{* * *}$ & 0.64 & \\
\hline q10-q11 & $-2.81^{* * *}$ & 0.43 & \\
\hline q12-q16 & $-2.66^{* * *}$ & 0.45 & \\
\hline \multicolumn{4}{|l|}{ Independent Variables } \\
\hline Growth & -0.06 & 0.09 & - \\
\hline Inflation & 0.08 & 0.09 & + \\
\hline Unemployment & 0.01 & 0.02 & + \\
\hline Export Growth & $-0.04^{* *}$ & 0.02 & - \\
\hline Import Growth & $0.03^{* *}$ & 0.02 & + \\
\hline Openness & $-0.01^{* *}$ & 0.01 & - \\
\hline REER (deviation from trend) & $-0.08^{* * *}$ & 0.03 & - \\
\hline Deposits/GDP (rate of growth) & $-0.05^{*}$ & 0.03 & - \\
\hline Claims on Government/GDP & $0.01^{*}$ & 0.01 & + \\
\hline Portfolio Investment/GDP & $0.06^{* * *}$ & 0.03 & + \\
\hline FDI/GDP & -0.01 & 0.11 & - \\
\hline
\end{tabular}

${ }^{*},{ }^{* *}$ and ${ }^{* * *}$ indicate significance at $10 \%, 5 \%$ and $1 \%$ respectevely.

Note: the inclusion of a dummy variable to account for lagged duration dependence turns out to be not significant, so we excluded it from our analysis. 
domestic asset markets, attracting capital inflows and, therefore, supporting the currency. Conversely, if growth is declining there would be pressures to ease financial policies, among them currency depreciation, to stimulate activity. Notwithstanding, our coefficient is not significant.

Our second variable, inflation, has the expected sign that, albeit again, is not significant: high inflation increases the likelihood of exit into a turbulent period. Kumar et al. (1998) argue that high inflation can increase vulnerability to crises through an impact on resource allocation, competitiveness, and macroeconomic stability. In an exchange rate peg (or relatively inflexible nominal exchange rate regime) a higher level of inflation than that of partner countries can lead to significant overvaluation in the real exchange rate.

A possible justification of the non-significance of the inflation variables lie in the inclusion of the REER variable. When we do not include REER, inflation is significant. In previous works, inflation is significant either when REER is excluded, as in Eichengreen et al. (1996), or when an inflation indicator is introduced by means of a dummy variable that reflects only high inflation regimes rather than absolute values, as in Kumar et al. (1998).

As we expected, high unemployment increases the vulnerability to crises. The slump in economic activity, reflected in a rise of unemployment, makes the Central Banks more attentive to domestic objectives, compromising the exchange rate target. But once again, our coefficient is not significant. We have included this variable in the final specification in rates of growth to take into account the historical different levels of unemployment rates in the countries under study. The inclusion of the variable in levels changes neither its sign, its significance feature, nor the behavior of the other variables.

As variables that reflect the health of the foreign sector we have included: exports, imports and an indicator of openness.

The export variable is included in relative terms to GDP and in rate of growth. The different studies on currency crises emphasize the role of a sharp slowdown in export growth as a key contributor to currency vulnerability. A slowdown in exports is likely to increase the probability of a crisis. Our study confirms this result: the sign for the coefficient of the export variable is negative and significant. A result consistent with Kumar et al. (1998). 
According to our estimates, import growth increases in the advance of a speculative attack, reflected by the positive sign and significant coefficient. Therefore, an increase in import growth helps to predict the probability of the occurrence of a currency crisis event.

Milesi-Ferreti and Razin (1998) argue that more open economies are less likely to suffer an exchange rate crash. The benefits of trade openness outweighs the higher vulnerability to external shocks. Openness reflects how connected the economy is to the rest of the world and stands here for trade liberalization. It is proxied by exports plus imports over GDP. We obtain a negative and significant expected sign, in line with Milesi-Ferreti and Razin's argument, and with the results of Kumar et al. (1998), but unable to find in Eichengreen et al. (1996).

The behavior of the latter three variables can be better understood if we consider the effects of the REER. The REER is found to be one of the most important indicators in assessing likely pressures against a currency (Kaminsky et al. (1998). We can consider the REER as a possible proxy for loss of international price competitiveness and exchange rate misalignment.

Following Kumar et al. (1998), REER can act as a channel for the contagion effect via a competitiveness effect: when one currency is devalued, the trading partners' position deteriorates vis à vis that economy. This would show up in the trade accounts with some lag, but investors act on the expectation of the impact and increases in the pressure on the other currencies may follow immediately. A higher value of the exchange rate index implies a more appreciated domestic real exchange rate. Therefore, we expect the coefficient on the real effective exchange rate index to be positive.

On the other hand, an appreciation of the real exchange rate relative to its historical value increases the degree of misalignment. Trend measures of the REER (based on the Hodrick Prescott filter) can provide an approximate measure of significant disequilibrium in the real exchange rate. We introduce the variable REER as deviations from this trend therefore, expecting a negative sign.

According to Table 4, the deviation of the REER from its trend variable 
is significant and has the correct sign. Table D (see Appendix) includes REER instead of its deviations from trend. Again, the sign is as expected and the coefficient is significant. Including REER or its deviation from trend has no effect either on the rest of the variables or in the shape of the baseline hazard function. Therefore, with both REER and deviations of REER from its historical trend, we support the hypothesis of REER as, first, a competitiveness indicator, with deteriorations of that indicator leading to higher probabilities of speculative attacks, and, second, as a measure of exchange rate misalignment: appreciations beyond its natural trend result in stronger likelihood of exit into a turbulent episode.

As a breaking point with the aforementioned works we introduce deposits over GDP (in terms of their growth rate) that serve as a proxy for the existence of deposit runs and loss of confidence in the banking system, or of the shrinkage of banks' balance sheets for other reasons. Our results show that the coefficient for this variable has the expected sign and is significant. The absence of falling deposits is reflected in a lower probability of a currency crisis event therefore, reflecting the influence of the banking sector over the likelihood of a currency crisis.

In order to capture Krugman's effect ${ }^{15}$ (domestic credit expansion) on the likelihood of a speculative attack, past empirical studies include the domestic credit variable. This variable is a mix of claims on central government, local governments, nonfinancial public enterprises, private sector, other banking institutions and nonbank financial institutions. But what Krugman emphasizes is not the behavior of all those components of the total domestic credit, but the credit to the government; the credit expansion due to the monetization of the government budget deficit. In order to capture the effect of this variable on the likelihood of a speculative attack, we should take into consideration only the claims on government (in net terms) by the central bank and other banks. We have not seen any study that makes such a consideration. We then include claims on government as one of our time-varying independent variables. Our results show the significance of this variable and indicate a higher probability of exit into a turbulent episode due to an increase of claims on government (relative to GDP).

\footnotetext{
${ }^{15}$ See Krugman (1979).
} 
In order to check the accuracy of our proposition, we have also estimated the model using domestic credit instead of claims on government. The result is shown in Table E (see Appendix): domestic credit has the wrong sign and it is not significant.

To double check, we have also estimated the model including both claims on government and claims on private sector. The first remains significant and with the correct sign, but the latter is not significant. Moreover, Eichengreen et al. (1996) introduce credit growth and fail to find a significant influence of this variable on the likelihood of occurrence of a currency crisis. Therefore, we conclude that claims on government is the variable that better reflects Krugman's effect.

The last two variables included in our regression analysis reflect the composition of capital inflows: portfolio investment and FDI, both variables deflated by domestic GDP. As Frankel and Rose (1996) and Kumar et al. (1998) argue, the hypothesis is that FDI is a safer way to finance investment than is portfolio investment. First, FDI is said to be directly tied to real investment in plants, equipment and infrastructure; whereas the other type of investment goes to consumption and, therefore, does not help to add productive capacity to the system, which is necessary to generate exports that go into the service of debt in the future. Second, the difference between these two types of capital inflows may be an important factor in determining the vulnerability of a country to its capital inflows. Portfolio flows are very sensitive to any changes in the international financial environment as well as to changes in investor sentiment. In the event of a crash, investors can suddenly dump portfolio investments, but multinational corporations cannot quickly sell their factories, that is, dump FDI.

Regarding portfolio investment, this variable is highly significant and has the expected sign: increases in portfolio investment raise the probability of occurrence of a currency crisis. Nonetheless, the FDI variable, even if it has the expected sign is not significant. We can only compare these results with the ones of Kumar et al. (1998), since Eichengreen et al. (1996) do not consider the effects of these kind of variables. Kumar et al. (1998) obtain the same effect regarding portfolio investment variable, a positive and significant effect. Nevertheless, they find a significant effect but negative, meaning that increases in FDI revert in higher likelihood of a crisis. The reason is prob- 
ably due to the different group of countries under study: emerging markets in their work, OECD countries in our paper.

Summarizing and comparing with Eichengreen et al. (1996) (that is the closest paper to ours, both in terms of country sample and on the construction of the dependent variable based on a $E M P$ index), we find a wide range of significant variables, in contrast of Eichengreen, Rose and Wyplosz's two macroeconomic significant variables (unemployment rate and inflation) plus the contagion variable. Therefore, our study allows a better understanding of the causes of currency crises.

Moreover, it still remains the interpretation of the second part of the output of our estimates, the base-line hazard and the corresponding hypothesis of duration dependence of exchange rate episodes of tranquility. We examine these considerations in the next section.

\subsection{Estimated Base-Line Hazard}

The scaled estimated base-line hazard for our semiparametric function model is plotted in Figure 3. With the base-line hazard we want to test whether time spent on the peg has an independent effect on the likelihood of a currency crisis event, that is, our hypothesis of a duration dependence beyond the control of time-varying variables.

The base-line hazard function shows a downward slope from the second quarter after the start of the peg. That is, the likelihood of exit into a currency crisis state declines with the length of the peg. Therefore, we can clearly state a negative duration dependence: the probability of leaving the peg decreases with duration. Our hypothesis on the existence of duration dependence, even after controlling for time-varying factors, is confirmed, and hence, the use of duration analysis to model the likelihood of currency crises is the optimal.

More specifically, in the first quarter, the probability of a speculative attack is lower than in the following one. That probability increases in the second quarter and remains around that level for the first year of the peg. These two facts seem to show that at the very beginning of the peg the agents are not very confident in the peg. After the first quarter, the agents test the exchange rate regime resulting in a higher likelihood of breaking the peg in 
Figure 3: Estimated Base-line Hazard

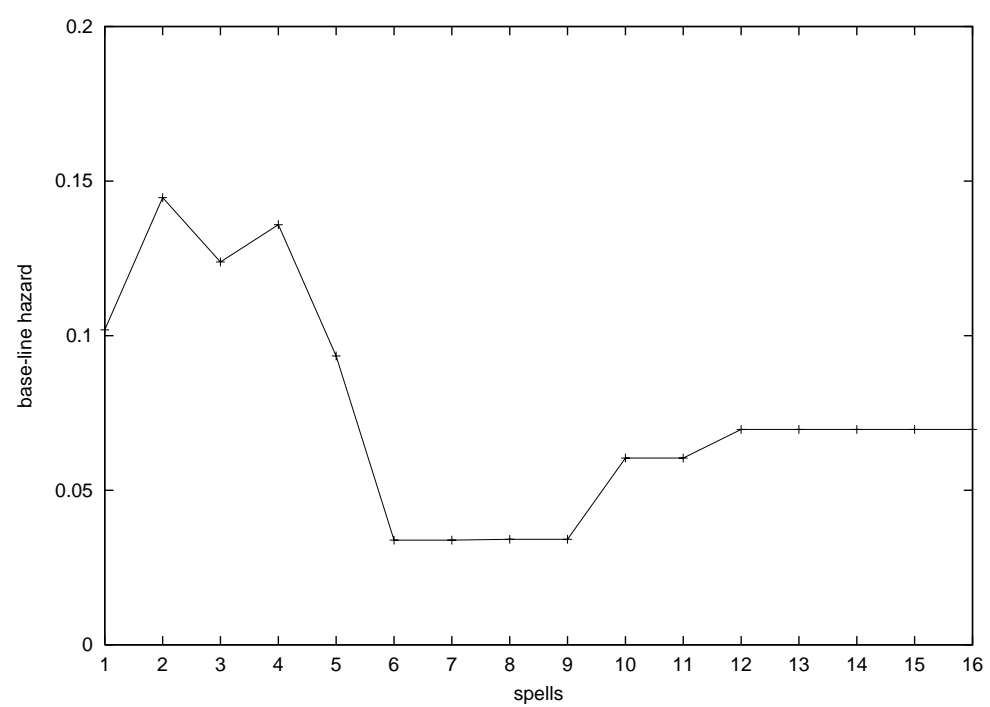

that quarter. After the first year, the probability of exit into a currency crisis state declines sharply, stabilizing by the end of the second year of the peg, to recover a little bit in the initial months of the third year and turning into a flat line afterwards. Concluding, this general downward slope of the curve indicates that agents get more confident as the peg goes on. This may suggest that a policy-maker gains credibility over time while on a peg, changing the political cost of realignment over the duration of the spell.

\section{Concluding Remarks}

In this paper, we have adopted a duration model towards the determination of the origins of a currency crisis event. We concentrate on the likelihood of a crisis for a country in a given period related to some explanatory variables. We differ, then, from the traditional empirical studies on currency crashes that adopt probit or logit models in their specifications. The use of duration models allows us to account for duration dependence among the determinants of the likelihood of speculative attacks, without neglecting the use of time-varying explanatory variables as used by other researchers. One of the 
main objectives of this paper is to test for time dependence, that is, the length of the time already spent on the peg as determinant of the probability of exit into a crisis state.

From our estimates, we first state the influence of some macro variables on the likelihood of exit into a turbulent state. Increases in the rate of growth of exports, decreases in the rate of growth of imports, and openness are associated with a decrease in the vulnerability of the currency to attacks. Appreciated REER is highly significant in predicting increases in the occurrence of a currency crisis, the same as increases in capital inflows in the form of portfolio investment. Claims on government help to predict the likelihood of a speculative attack, increases in that credit position raise the likelihood of exit into a turbulent state; whereas increases in the rate of growth of deposits over GDP decrease the probability of a crisis event.

Regarding the duration dependence which characterizes our data, the maximum probabilities of exit are given at the start of the peg (tranquil period), but with a clear tendency to decrease after the first year of the peg. That is, we can clearly state a negative and highly significant duration dependence. This fact may suggest the existence of a political cost of realignment that changes over the duration of the spell: growing credibility surrounding an exchange-rate-based stabilization program might reduce the probability that the peg will be abandoned. 


\section{A Appendix}

Table A: Identification of Currency Crises

\begin{tabular}{ccccc}
\hline \hline date & country & $\begin{array}{l}\text { EMP index } \\
\text { unweighted }\end{array}$ & $\begin{array}{l}\text { EMP index } \\
\text { weighted }\end{array}$ & third measure \\
\hline \hline
\end{tabular}

\begin{tabular}{|c|c|c|c|}
\hline \multicolumn{2}{|c|}{ Australia } & & \\
\hline 1974:3 & yes & & yes \\
\hline 1974:4 & & yes & yes \\
\hline 1979:1 & yes & & yes \\
\hline 1981:3 & yes & & yes \\
\hline 1985:1 & & yes & yes \\
\hline $1985: 2$ & & yes & yes \\
\hline 1986:3 & & yes & yes \\
\hline 1989:2 & & & yes \\
\hline
\end{tabular}

\begin{tabular}{llll}
\multicolumn{2}{c}{ Austria } & & \\
\hline $1970: 1$ & & yes & yes \\
$1970: 2$ & yes & & yes \\
$1970: 3$ & yes & & yes \\
$1970: 4$ & & & yes \\
$1971: 1$ & yes & yes & yes \\
\cline { 2 - 4 } $1971: 3$ & & yes \\
\cline { 2 - 4 } $1973: 1$ & yes & yes \\
$1973: 2$ & & yes & yes \\
\cline { 2 - 4 } $1978: 4$ & yes & yes \\
\cline { 2 - 4 } $1981: 1$ & yes & yes \\
\cline { 2 - 3 } $1992: 3$ & yes & yes \\
\cline { 2 - 3 } & yes & \\
\hline \hline
\end{tabular}


Continuation Table A

\begin{tabular}{lcccc}
\hline \hline date country & $\begin{array}{l}\text { EMP index } \\
\text { unweighted }\end{array}$ & $\begin{array}{l}\text { EMP index } \\
\text { weighted }\end{array}$ & third measure \\
\hline \hline
\end{tabular}

\begin{tabular}{llll}
\hline & & & \\
\hline $1970: 1$ & & & \\
$1970: 2$ & & yes & yes \\
$1970: 3$ & yes & & yes \\
\cline { 2 - 4 } $1973: 2$ & yes & yes & yes \\
\cline { 2 - 4 } $1976: 1$ & yes & yes \\
\cline { 2 - 4 } $1979: 3$ & yes & yes \\
\cline { 2 - 4 } $1981: 1$ & yes & yes \\
$1981: 4$ & & yes & yes \\
$1982: 1$ & & yes & yes \\
$1982: 2$ & & & yes \\
$1992: 3$ & yes & yes & yes \\
\cline { 2 - 4 } $1993: 2$ & & & yes
\end{tabular}

\begin{tabular}{|c|c|c|c|}
\hline \multicolumn{2}{|c|}{ Canada } & \multirow[b]{2}{*}{ yes } & \multirow[b]{2}{*}{ yes } \\
\hline $1977: 1$ & & & \\
\hline 1977:4 & & yes & \\
\hline 1978:4 & & yes & \\
\hline 1980:1 & yes & & \\
\hline 1981:2 & yes & yes & yes \\
\hline 1982:2 & & yes & yes \\
\hline 1984:2 & & yes & \\
\hline 1992:1 & & yes & yes \\
\hline 1992:4 & & yes & yes \\
\hline 1994:2 & & yes & \\
\hline 1995:1 & & yes & \\
\hline
\end{tabular}


Continuation Table A

\begin{tabular}{|c|c|c|c|c|}
\hline date & country & $\begin{array}{l}\text { EMP index } \\
\text { unweighted }\end{array}$ & $\begin{array}{l}\text { EMP index } \\
\text { weighted }\end{array}$ & third measure \\
\hline \multicolumn{5}{|c|}{ Denmark } \\
\hline 1970:1 & & & & yes \\
\hline 1970:2 & & yes & & yes \\
\hline 1971:2 & & yes & yes & yes \\
\hline 1971:3 & & & yes & yes \\
\hline 1973:3 & & & yes & yes \\
\hline 1976:3 & & yes & & yes \\
\hline $1977: 2$ & & & yes & yes \\
\hline $1977: 3$ & & & yes & yes \\
\hline 1977:4 & & yes & yes & yes \\
\hline 1979:4 & & & yes & yes \\
\hline 1980:1 & & & yes & yes \\
\hline 1982:1 & & & yes & yes \\
\hline 1982:2 & & & yes & yes \\
\hline 1992:3 & & yes & & yes \\
\hline 1993:3 & & & & yes \\
\hline 1995:1 & & & yes & yes \\
\hline
\end{tabular}

\section{Finland}

\begin{tabular}{|c|c|c|c|}
\hline 1970:1 & & yes & \\
\hline 1970:3 & yes & & yes \\
\hline 1973:1 & yes & & yes \\
\hline 1973:3 & & yes & yes \\
\hline 1975:1 & yes & & \\
\hline 1977:2 & & yes & yes \\
\hline 1982:4 & & & yes \\
\hline 1991:4 & & yes & yes \\
\hline 1992:1 & & yes & yes \\
\hline 1992:3 & yes & yes & yes \\
\hline 1993:1 & & yes & yes \\
\hline 1993:3 & yes & & yes \\
\hline
\end{tabular}


Continuation Table A

\begin{tabular}{llll}
\hline \hline date country & $\begin{array}{l}\text { EMP index } \\
\text { unweighted }\end{array}$ & $\begin{array}{l}\text { EMP index } \\
\text { weighted }\end{array}$ & third measure \\
\hline \hline
\end{tabular}

\section{France}

\begin{tabular}{llll}
\hline $1971: 3$ & & & yes \\
\cline { 2 - 3 } $1973: 3$ & & yes & yes \\
$1973: 4$ & & & yes \\
$1974: 1$ & yes & yes & yes \\
$1974: 2$ & & yes & yes \\
\cline { 2 - 4 } $1976: 1$ & & yes \\
$1976: 2$ & yes & yes \\
$1976: 3$ & yes & yes \\
$1976: 4$ & yes & yes \\
\cline { 2 - 4 } $1978: 1$ & & yes & yes \\
\cline { 2 - 4 } $1978: 4$ & yes & yes \\
$1981: 4$ & & yes & yes \\
\cline { 2 - 4 } $1982: 3$ & & yes & yes \\
\cline { 2 - 4 } $1983: 2$ & yes & yes \\
\cline { 2 - 4 } $1992: 3$ & yes & & yes
\end{tabular}

\begin{tabular}{llll}
\multicolumn{1}{c}{ Greece } & & & \\
\hline $1971: 3$ & yes & yes & yes \\
\cline { 2 - 4 } $1973: 2$ & yes & yes & yes \\
$1973: 3$ & & & yes \\
$1973: 4$ & & & yes \\
\cline { 2 - 4 } $1974: 3$ & & yes \\
\cline { 2 - 4 } $1980: 1$ & yes & yes \\
\cline { 2 - 4 } $1982: 2$ & yes & yes & yes \\
\cline { 2 - 4 } $1983: 1$ & & yes & yes \\
\cline { 2 - 4 } $1985: 4$ & & yes & yes \\
& & & \\
\hline \hline
\end{tabular}


Continuation Table A

\begin{tabular}{|c|c|c|c|c|}
\hline date & country & $\begin{array}{l}\text { EMP index } \\
\text { unweighted }\end{array}$ & $\begin{array}{l}\text { EMP index } \\
\text { weighted }\end{array}$ & third measure \\
\hline \multicolumn{5}{|c|}{ Ireland } \\
\hline 1970:2 & & yes & & yes \\
\hline 1970:3 & & yes & & yes \\
\hline 1970:4 & & & & yes \\
\hline 1972:2 & & & yes & yes \\
\hline 1972:3 & & & & yes \\
\hline 1973:1 & & yes & & yes \\
\hline 1973:3 & & & yes & yes \\
\hline 1976:2 & & & & yes \\
\hline 1976:4 & & & yes & yes \\
\hline 1986:3 & & & & yes \\
\hline 1992:3 & & yes & yes & yes \\
\hline
\end{tabular}

Italy

\begin{tabular}{llll}
\hline $1970: 2$ & yes & & yes \\
$1970: 3$ & yes & & yes \\
\cline { 2 - 4 } $1973: 1$ & yes & yes & \\
$1973: 2$ & & & yes \\
$1973: 3$ & & & yes \\
\cline { 2 - 4 } $1974: 2$ & yes & yes & yes \\
\cline { 2 - 4 } $1974: 4$ & & & yes \\
\cline { 2 - 4 } $1975: 4$ & yes & yes & yes \\
$1976: 1$ & & & yes \\
$1992: 3$ & yes & & yes \\
$1992: 4$ & & & yes \\
$1993: 1$ & & yes \\
\cline { 2 - 3 } $1995: 1$ & & & \\
$1995: 2$ & & & \\
\hline \hline
\end{tabular}


Continuation Table A

\begin{tabular}{|c|c|c|c|c|}
\hline date & country & $\begin{array}{l}\text { EMP index } \\
\text { unweighted }\end{array}$ & $\begin{array}{l}\text { EMP index } \\
\text { weighted }\end{array}$ & third measure \\
\hline \multicolumn{5}{|c|}{ Japan } \\
\hline 1972:1 & & yes & & \\
\hline 1974:3 & & yes & & \\
\hline 1979:1 & & yes & & yes \\
\hline 1979:2 & & & & yes \\
\hline 1979:4 & & & & yes \\
\hline 1980:1 & & yes & & yes \\
\hline 1989:2 & & yes & & yes \\
\hline 1989:3 & & yes & & \\
\hline 1990:1 & & yes & & \\
\hline 1991:1 & & & yes & yes \\
\hline 1995:3 & & & & yes \\
\hline 1995:4 & & & & yes \\
\hline 1997:1 & & & & yes \\
\hline
\end{tabular}

\begin{tabular}{lccc}
\multicolumn{2}{c}{ Netherlands } & & \\
\hline $1970: 2$ & yes & & yes \\
$1970: 3$ & yes & yes \\
\cline { 2 - 4 } $1973: 2$ & & yes & yes \\
$1973: 3$ & yes & yes & yes \\
\cline { 2 - 4 } $1978: 3$ & & & yes \\
$1978: 4$ & yes & yes & yes \\
\cline { 2 - 4 } $1980: 3$ & & & \\
\cline { 2 - 4 } $1989: 3$ & & & yes \\
\cline { 2 - 4 } $1992: 3$ & yes & & \\
& & &
\end{tabular}


Continuation Table A

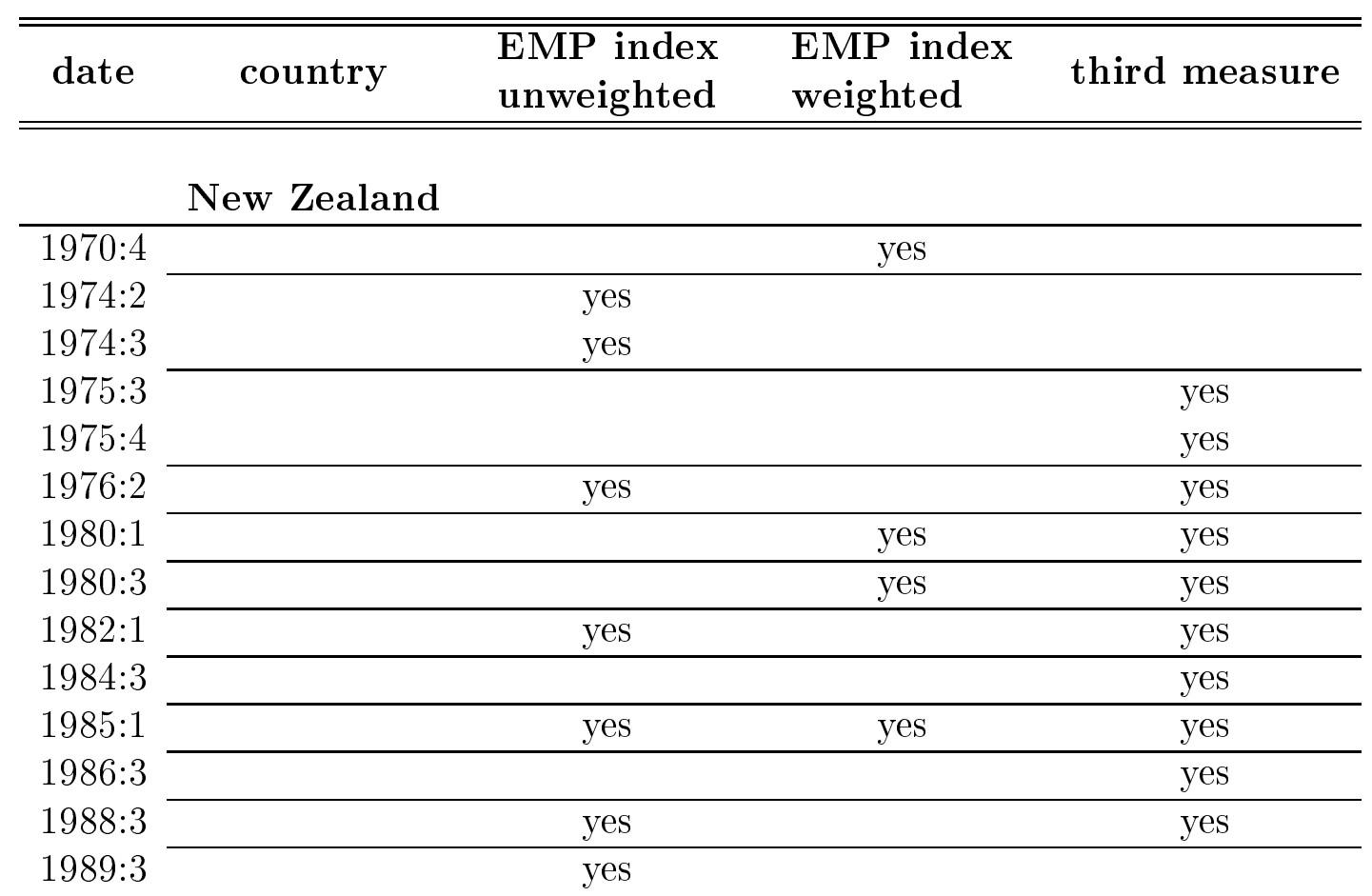

\begin{tabular}{|c|c|c|c|}
\hline \multicolumn{3}{|c|}{ Norway } & \multirow[b]{2}{*}{ yes } \\
\hline 1970:2 & yes & & \\
\hline 1970:3 & yes & & yes \\
\hline 1973:1 & yes & & yes \\
\hline 1973:3 & & yes & yes \\
\hline 1977:4 & yes & yes & yes \\
\hline $1982: 3$ & & & yes \\
\hline 1982:4 & & yes & yes \\
\hline 1986:2 & & yes & yes \\
\hline 1986:3 & & yes & yes \\
\hline 1986:4 & & yes & yes \\
\hline 1987:4 & yes & & \\
\hline 1992:3 & yes & & yes \\
\hline
\end{tabular}


Continuation Table A

\begin{tabular}{|c|c|c|c|c|}
\hline date & country & $\begin{array}{l}\text { EMP index } \\
\text { unweighted }\end{array}$ & $\begin{array}{l}\text { EMP index } \\
\text { weighted }\end{array}$ & third measure \\
\hline
\end{tabular}

\begin{tabular}{llll}
\hline \hline & & & \\
& & & \\
\hline $1972: 4$ & & & \\
\cline { 2 - 4 } $1976: 2$ & & yes \\
$1977: 1$ & & yes \\
$1977: 2$ & & yes & yes \\
\cline { 2 - 4 } $1978: 2$ & & yes \\
\cline { 2 - 4 } $1978: 4$ & & yes & yes \\
\cline { 2 - 4 } $1983: 3$ & & & yes \\
\cline { 2 - 4 } $1992: 3$ & yes & & yes
\end{tabular}

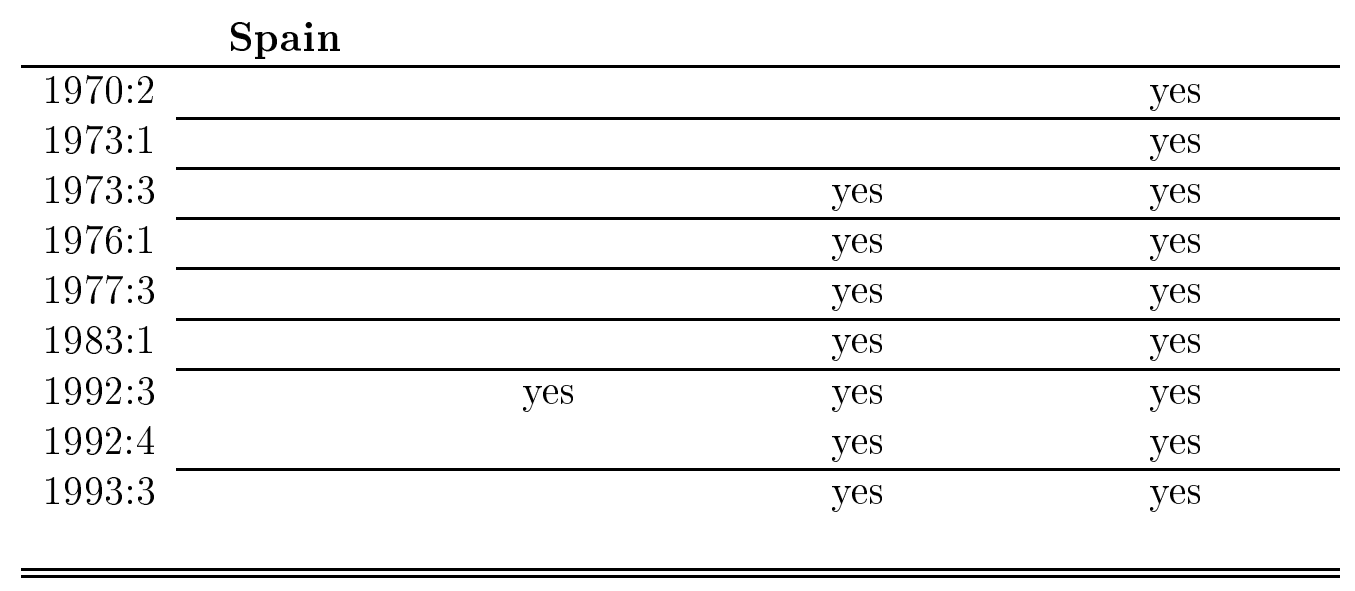


Continuation Table A

\begin{tabular}{|c|c|c|c|c|}
\hline date & country & $\begin{array}{l}\text { EMP index } \\
\text { unweighted }\end{array}$ & $\begin{array}{l}\text { EMP index } \\
\text { weighted }\end{array}$ & third measure \\
\hline \multicolumn{5}{|c|}{ Sweden } \\
\hline 1970:1 & & yes & yes & yes \\
\hline 1970:2 & & yes & & yes \\
\hline 1970:3 & & yes & & yes \\
\hline 1970:4 & & yes & & yes \\
\hline 1973:1 & & yes & & yes \\
\hline 1973:2 & & & yes & yes \\
\hline 1973:3 & & & & yes \\
\hline 1977:3 & & & & yes \\
\hline 1977:4 & & & & yes \\
\hline 1981:4 & & & yes & yes \\
\hline 1982:4 & & & yes & yes \\
\hline 1987:4 & & yes & & \\
\hline 1992:3 & & yes & & yes \\
\hline 1992:4 & & & & yes \\
\hline 1993:1 & & & & yes \\
\hline \multicolumn{5}{|c|}{ Switzerland } \\
\hline 1970:1 & & yes & & yes \\
\hline 1970:3 & & yes & & yes \\
\hline 1971:1 & & yes & & yes \\
\hline 1972:4 & & & yes & yes \\
\hline 1973:1 & & yes & & yes \\
\hline 1973:3 & & & yes & yes \\
\hline 1978:4 & & & & yes \\
\hline 1979:1 & & & & yes \\
\hline 1981:1 & & yes & & yes \\
\hline 1982:2 & & & & yes \\
\hline 1992:3 & & & & yes \\
\hline
\end{tabular}


Continuation Table A

\begin{tabular}{|c|c|c|c|c|}
\hline date & country & $\begin{array}{l}\text { EMP index } \\
\text { unweighted }\end{array}$ & $\begin{array}{l}\text { EMP index } \\
\text { weighted }\end{array}$ & third measure \\
\hline \multicolumn{5}{|c|}{ U.K. } \\
\hline 1970:2 & & yes & & yes \\
\hline 1970:3 & & yes & & yes \\
\hline 1972:1 & & & yes & \\
\hline 1972:2 & & & & yes \\
\hline 1972:3 & & yes & & yes \\
\hline 1973:3 & & & & yes \\
\hline 1976:2 & & & & yes \\
\hline 1976:4 & & & & yes \\
\hline 1981:4 & & & yes & yes \\
\hline 1983:1 & & & & yes \\
\hline 1986:1 & & & & yes \\
\hline 1986:3 & & & & yes \\
\hline 1986:4 & & & & yes \\
\hline 1992:3 & & yes & & yes \\
\hline 1992:4 & & & yes & yes \\
\hline
\end{tabular}

\begin{tabular}{|c|c|c|c|}
\hline 1970:2 & yes & & yes \\
\hline 1970:3 & yes & & yes \\
\hline 1970:4 & yes & & yes \\
\hline 1971:3 & yes & yes & yes \\
\hline 1973:1 & yes & & yes \\
\hline 1973:2 & & & yes \\
\hline 1973:3 & & & yes \\
\hline 1977:2 & & yes & \\
\hline 1979:3 & yes & & yes \\
\hline 1980:4 & & yes & yes \\
\hline 1985:4 & & & yes \\
\hline 1986:1 & & & yes \\
\hline 1987:1 & & & yes \\
\hline 1992:3 & yes & yes & yes \\
\hline
\end{tabular}


Table B: Identification of Currency Crises and Official Events

\begin{tabular}{|c|c|}
\hline Date & Events \\
\hline 1967 & $\begin{array}{l}\text { Devaluation } £ \\
\text { Beginning of the events towards the breakdown } \\
\text { of Bretton Woods }\end{array}$ \\
\hline Early'71 & Foreign CB buy $\$$ to prevent the $\$$ from depreciating \\
\hline May'71 & $\begin{array}{l}\text { German CB buys a huge amount of } \$ \text {, not useful } \\
\text { Suspended intervention } \\
\text { German and Dutch authorities float their currency }\end{array}$ \\
\hline August'71 & US suspension of the link between $\$$ and gold \\
\hline Dec.'71 & $\begin{array}{l}\text { Smithsonian agreement: intention of re-instituting a } \\
\text { system of stable exchange rates } \\
\circ 8 \% \text { devaluation } \$ \\
\circ 17 \% \text { revaluation yen } \\
\circ 4 \% \text { devaluation DM } \\
\text { ○ bands enlarges to } 2.25 \% \\
\text { It lasts } 14 \text { months (to February }{ }^{\prime} 73 \text { ) }\end{array}$ \\
\hline 24 April'72 & $\begin{array}{l}\text { Basle Agreement: snake in the }(\$) \text { tunnel: } 6 \text { EC members } \\
\text { (Germany, France, Italy, Belgium, Luxembourg, } \\
\text { The Netherlands) agree to halve the margin of the } \\
\text { Smithsonian agreement }\end{array}$ \\
\hline 1 May'72 & Denmark, UK, Ireland join the snake \\
\hline 23 Мау’72 & Norway joins the snake \\
\hline 23 June'72 & $£$ and Irish punt withdraw \\
\hline
\end{tabular}




\section{Continuation Table B}

\begin{tabular}{|c|c|}
\hline Date & Events \\
\hline 27 June'72 & Denmark withdraws \\
\hline June'72 & $\begin{array}{l}£ \text { floats } \\
\text { Speculation against the } \$ \text { in the following months }\end{array}$ \\
\hline 10 Oct.'72 & Denmark returns \\
\hline 13 Feb.'73 & Italy withdraws \\
\hline Early'73 & $\begin{array}{l}\text { Swiss franc floats against the } \$ \\
\$ \text { devaluation } \\
\text { Yen float against the } \$ \\
\text { French Franc floats } \\
\text { DM floats }\end{array}$ \\
\hline 19 March'73 & $\begin{array}{l}\text { Floating of the } \$ \text { (end of Bretton Woods), the tunnel } \\
\text { disappeared leaving the snake as a joint float for the } \\
\text { participants } \\
\text { Sweden becomes associated } \\
\text { DM revaluation, } 3 \% \text {, because of the depreciation of the } \$ \text { that } \\
\text { creates tensions in the snake, but this is not enough, so in } \Rightarrow\end{array}$ \\
\hline June'73 & $\begin{array}{l}\text { DM revaluation by } 5.5 \% \\
\text { Norwegian krone devaluated by } 13 \% \\
\text { Dannish krone devaluated by } 6 \% \\
\text { Finnish markka devaluated } 7 \%\end{array}$ \\
\hline 17 Sept.'73 & Dutch guilder revaluation $5 \%$ \\
\hline 16 Nov.'73 & Norwegian krone revaluation $5 \%$ \\
\hline Middle'73 & First oil shock $\rightarrow \$$ begins to appreciate against DM and yen \\
\hline
\end{tabular}




\section{Continuation Table B}

\begin{tabular}{|c|c|}
\hline Date & Events \\
\hline 19 Jan.'74 & $\begin{array}{l}\text { France withdraws (because of problems derived from the oil shock) } \\
\text { French franc, Belgium-Luxembourg franc and the two } \\
\text { Scandinavian currencies of Denmark and Sweden are the } \\
\text { weaker currencies; DM and Dutch guilder are the stronger } \\
\text { currencies } \Rightarrow \text { Clear division in the snake }\end{array}$ \\
\hline 10 July’75 & France returns \\
\hline Nov.'75 & Ramboulliet meeting: legalizes floating \\
\hline 76 & IMF legalizes the non-system \\
\hline 9 Feb.'76 & Peseta devaluated by $13 \%$ \\
\hline 15 March’76 & $\begin{array}{l}\text { France withdraws again (because Chirac implements fiscal } \\
\text { expansion in the autumn'75 as recession deepened) }\end{array}$ \\
\hline August'76 & $\begin{array}{l}\text { Bundesbank intervention in favour of the smaller non-German } \\
\text { participants in the snake }\end{array}$ \\
\hline 17 Oct.'76 & $\begin{array}{l}\text { Frankfurt realignment: } \\
\text { ○ Danish krone devaluation } 6 \% \\
\circ \text { Dutch guilder devaluation } 2 \% \\
\circ \text { Belgian Franc devaluation } 2 \% \\
\circ \text { Norwegian kroner devaluation } 3 \% \\
\circ \text { Swedish kroner devaluation } 3 \%\end{array}$ \\
\hline Second half' 77 & $\$$ begins to weaken \\
\hline 3 July'77 & Peseta is allowed to float to a $20 \%$ depreciation \\
\hline 78 & $\begin{array}{l}\text { Kingston (Jamaica): second amendment to IMF articles of } \\
\text { agreement takes effect, legalizing the float and reducing the } \\
\text { monetary role of gold }\end{array}$ \\
\hline
\end{tabular}




\section{Continuation Table B}

\begin{tabular}{|c|c|}
\hline Date & Events \\
\hline Early'78 & $\begin{array}{l}\text { Despite intervention of American, Germany and Japanese } \\
\text { authorities, } \$ \text { continues to fall } \\
\text { Appreciation DM }(7 \%) \text { difficult to handle for the other } \\
\text { currencies }\end{array}$ \\
\hline 13 Feb.'78 & Norwegian krone devaluation $8 \%$ \\
\hline 17 Oct.'78 & $\begin{array}{l}\text { DM revaluated } 4 \% \\
\text { Dutch guilder revaluated } 2 \% \\
\text { Belgian franc revaluated } 2 \%\end{array}$ \\
\hline Nov.'78 & More interventions to support the $\$$ \\
\hline 17 Dec.'78 & Norway announces decision to withdraw \\
\hline 13 March'79 & $\begin{array}{l}\text { EMS comes into being (with the snake participants) } \\
\text { Belgium franc, Danish krone, DM, French franc, } \\
\text { Irish punt, Lux. Franc and Dutch guilder band of } \\
2.25 \% \text { and Italian lira band of } 6 \%\end{array}$ \\
\hline July'79 & UK joins EMS \\
\hline Sept.'79 & $\begin{array}{l}\text { Bundesbank intervenes to support: } \$ \text {, Belgian franc } \\
\text { and Danish krone }\end{array}$ \\
\hline 24 Sept.'79 & $\begin{array}{l}\text { DM revaluation } 2 \% \\
\text { Danish krone devaluation } 2.9 \%\end{array}$ \\
\hline Oct.'79 & Dramatic tightening of monetary policy in US \\
\hline 30 Nov.'79 & $\begin{array}{l}\text { Dannish krone devaluated by } 4.8 \% \text { to restore competitiveness } \\
\text { (with respect to ECU) }\end{array}$ \\
\hline
\end{tabular}




\section{Continuation Table B}

\begin{tabular}{|c|c|}
\hline Date & Events \\
\hline $\begin{array}{l}\text { From Nov'79 } \\
\text { to Feb.' } 81\end{array}$ & $\begin{array}{l}\text { Fiscal expansion in Germany: interest differential in favour } \\
\text { of the weaker currencies } \rightarrow \text { DM near floor of band a lot } \\
\text { of times, requiring substantial interventions }\end{array}$ \\
\hline Feb.' 81 & $\begin{array}{l}\text { Bundesbank tights monetary policy: sharp increase in } \\
\text { interest rates } \rightarrow \text { DM to the top of the band }\end{array}$ \\
\hline 22 March'81 & Italy $6 \%$ devaluation with respect ECU \\
\hline Oct.'81 & $\begin{array}{l}\text { DM revaluation } 5.5 \% \\
\text { French franc devaluation } 3 \% \\
\text { Dutch guilder revaluation } 5.5 \% \\
\text { Belgium, Luxembourg, Denmark and Ireland: technically } \\
\text { chosen as pivots, but the realignment implied devaluation } \\
\text { around } 2 \%\end{array}$ \\
\hline 22 Feb.' 82 & $\begin{array}{l}\text { Belgium } 8.5 \% \text { devaluation } \\
\text { Denmark } 3 \% \text { devaluation } \\
\text { (with respect to ECU) }\end{array}$ \\
\hline 14 June'82 & $\begin{array}{l}\text { DM revaluation } 4.25 \% \\
\text { Guilder revaluation } 4.25 \% \\
\text { French franc devaluation } 5.75 \% \\
\text { Lira devaluation } 2.75 \% \\
\text { (with respect ECU) }\end{array}$ \\
\hline 2 Oct.' 82 & Sweden devaluation $15.9 \%$ \\
\hline 4 Dec.' 82 & Peseta is devaluated by $8 \%$ \\
\hline
\end{tabular}




\section{Continuation Table B}

\begin{tabular}{|c|c|}
\hline Date & Events \\
\hline 21 March'83 & $\begin{array}{l}\text { DM revaluation } 5.5 \% \\
\text { Dutch guilder revaluation } 4.25 \% \\
\text { French franc devaluation } 5.75 \% \\
\text { Italian lira devaluation } 2.75 \% \\
\text { (with respect ECU) }\end{array}$ \\
\hline $1980-85$ & Appreciation of the $\$$ because of tight monetary policy \\
\hline $21 \mathrm{July}^{\prime} 85$ & Lira devaluation $8 \%$ with respect to DM \\
\hline Sept.' 85 & $\begin{array}{l}\text { Plaza agreement (G5: France, Germany, Japan, UK and US): } \\
\text { Intervention selling } \$ \text { for DM and yens to stop appreciation } \$\end{array}$ \\
\hline 85 & $\$$ starts to depreciate \\
\hline 86 & $\begin{array}{l}\text { Depreciation } \$ \\
\text { Appreciation yen }\end{array}$ \\
\hline 7 April'86 & $\begin{array}{l}\text { DM and Dutch gulder revaluation } 3 \% \\
\text { Danish krone and Belgian franc revaluation } 1 \% \\
\text { French franc devaluation } 3 \% \\
\text { (with respect ECU) }\end{array}$ \\
\hline 4 August'86 & Irish punt devaluation $8 \%$ (with respect to ECU) \\
\hline 12 May'86 & Norwegian krone is devalued by $10.7 \%$ \\
\hline Oct.'86 & $\begin{array}{l}\text { Governments want to stabilize } \$ \text {-yen exchange rate: they do } \\
\text { not want the } \$ \text { to depreciate further } \rightarrow \text { CBs start to } \\
\text { intervene buying } \$\end{array}$ \\
\hline
\end{tabular}




\section{Continuation Table B}

\begin{tabular}{|c|c|}
\hline Date & Events \\
\hline 12 Jan.' 87 & $\begin{array}{l}\text { DM devaluation } 3 \% \\
\text { Guilder devaluation } 3 \% \\
\text { Belgian-Luxembourg franc devaluation } 2 \% \\
\text { (with respect to ECU) }\end{array}$ \\
\hline Feb.' 87 & G5 in Paris, Louvre Accord: CBs intervene buying $\$$ \\
\hline Autumn'87 & $\begin{array}{l}\$ \text { continues to fall } \\
\text { Mid October a small increase in DM interest rates very } \\
\text { criticized, panic in US } \rightarrow \$ \text { falls despite intervention }\end{array}$ \\
\hline Oct.'87 & French franc falls but reverts in \\
\hline Nov.' 87 & $\begin{array}{l}\text { By adjustment in interest rate differentials with } \\
\text { respect Germany }\end{array}$ \\
\hline Early'88 & Depreciation $\$$ ends abruptly because of intervention \\
\hline July'89 & Peseta joins EMS, 6\% band \\
\hline 7 Jan.'90 & $\begin{array}{l}\text { Spain and Italy reduce margins to } \pm 2.25 \% \\
\text { Italian lira devaluation } 3.75 \%\end{array}$ \\
\hline Oct.'90 & $\begin{array}{l}\text { UK joins EMS ( } 6 \% \text { band) } \\
\text { Norway pegs its currency as it moves towards } \\
\text { applying for EU membership }\end{array}$ \\
\hline May’91 & $\begin{array}{l}\text { Sweden and Finland peg their currencies as they move } \\
\text { towards applying for EU membership }\end{array}$ \\
\hline 15 Nov.'91 & Finland devaluation $12.3 \%$ \\
\hline
\end{tabular}




\section{Continuation Table B}

\begin{tabular}{|c|c|}
\hline Date & Events \\
\hline April'92 & Portugal joins EMS ( $6 \%$ band) \\
\hline 2 June'92 & $\begin{array}{l}\text { Tensions in the EMS because of the narrow majority against the } \\
\text { Maastricht treaty by Denmark }\end{array}$ \\
\hline Summer'92 & $\begin{array}{l}\text { UK postpones ratification of the treaty } \\
\text { Weakness of } \$\end{array}$ \\
\hline July'92 & Increase in German interest rate to $8.5 \%$ \\
\hline 8 Sept.'92 & Finnish markka has to abandon its ECU peg \\
\hline 10-11 Setp.'92 & $\begin{array}{l}\text { Lira under pressure: falls below its EMS floor. Massive } \\
\text { interventions by Banca d'Italia and Bundesbank }\end{array}$ \\
\hline 14 Setp.'92 & $\begin{array}{l}\text { Cut on German interest rate } \\
\text { Italian lira devaluation } 3.5 \%\end{array}$ \\
\hline 16 Sept'92 & $\begin{array}{l}\text { Heavy interventions failed to lift sterling from its EMS floor } \\
\text { Sweden raise its marginal lending rate } \\
\text { Temporarily suspension of both sterling and lira from participation } \\
\text { Devaluation } 5 \% \text { of peseta }\end{array}$ \\
\hline 19 Nov.92 & Swedish krona breaks its link \\
\hline 22 Nov.'92 & $\begin{array}{l}\text { Peseta devaluation } 6 \% \text { (capital controls) } \\
\text { Escudo devaluation } 6 \% \text { (follows Spain) }\end{array}$ \\
\hline 10 Dec.'92 & $\begin{array}{l}\text { Norway discontinues the peg on the ECU and its currency is } \\
\text { allowed to float }\end{array}$ \\
\hline 30 Jan.'93 & Punt devaluation $10 \%$ \\
\hline
\end{tabular}




\section{Continuation Table B}

\begin{tabular}{|c|c|}
\hline 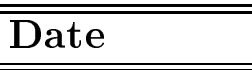 & Events \\
\hline 13 May'93 & $\begin{array}{l}\text { Peseta devaluation } 8 \% \\
\text { Escudo devaluation } 6.5 \%\end{array}$ \\
\hline July'93 & $\begin{array}{l}\text { French franc under pressure: intervention } \\
\text { Danish krone under pressure: intervention }\end{array}$ \\
\hline 29 July'93 & France, Belgium and Denmark fall below their EMS floor \\
\hline 1 August'93 & $\begin{array}{l}\text { Widening of the fluctuations margins to } 15 \% \\
\text { Over the first month after the decision Danish krone, } \\
\text { French franc and Belgian franc use a substantial } \\
\text { part of the new margins }\end{array}$ \\
\hline Autumn'93 & Danish krone, French franc and Belgian franc recover \\
\hline Jan.'95 & Austria joins EMS \\
\hline April-May’95 & $\begin{array}{l}\text { Falling French franc because Jacques Chirac's campaign } \\
\text { promises of more expansionary policies } \\
\text { Lira and Swedish krone weak } \\
\$ \text { depreciates }\end{array}$ \\
\hline May'95 & $\begin{array}{l}\text { Peseta devaluation } 7 \% \\
\text { Escudo devaluation } 3.5 \%\end{array}$ \\
\hline 96 & $\begin{array}{l}\text { French franc most of the time weak } \\
\text { Irish Punt strong }\end{array}$ \\
\hline Autumn'96 & Finnish markka and lira enter EMS \\
\hline
\end{tabular}


Table C: Currency Crises and Associated Events

\begin{tabular}{|c|c|}
\hline $\begin{array}{l}\text { Beginning of the } \\
\text { Currency Crisis }\end{array}$ & Associated Event (if applicable) \\
\hline
\end{tabular}

Australia

1974:3

1979:1

1981:3

1985:1

1986:3

1989:2

Austria

1970:1

1971:3

US suspension link $\$$ /gold

1973:1

1978:4

19 March: floating of the $\$$, the tunnel (of the snake)

disappears; DM revaluated by $3 \%$ because depreciation

of the $\$$ that creates tensions in the snake

1992:3

17 Oct. DM revaluated by $4 \%$

1993:3

EMS tensions: cut on German interest rates, 14 Sept.

EMS tensions: widening of the fluctuations margins

to $\pm 15 \%$

Belgium

1970:1

1973:2

DM revaluated by $5.5 \%$ (tensions derived from the

floating of the $\$$ the previous quarter)

1976:1 (French franc withdraws)

1979:3 Sept. Bundesbank intervenes to support the Belgian

1981:1 franc Feb. Bundesbank tights monetary policy: tensions in the snake

1981:4 Oct. DM revaluated by $5.5 \%$ and Belgian franc devaluated by $2 \%$

1992:3 EMS tensions: cut on German interest rates, 14 Sept

1993:2 EMS tensions 
Continuation Table C

\begin{tabular}{ll}
\hline \hline Beginning of the & \\
Currency Crisis & Associated Event (if applicable) \\
\hline \hline
\end{tabular}

\begin{tabular}{|c|c|}
\hline \multicolumn{2}{|l|}{ Canada } \\
\hline \multicolumn{2}{|l|}{$1977: 1$} \\
\hline \multicolumn{2}{|l|}{ 1981:2 } \\
\hline \multicolumn{2}{|l|}{ 1982:2 } \\
\hline \multicolumn{2}{|l|}{ 1992:1 } \\
\hline \multicolumn{2}{|l|}{ 1992:4 } \\
\hline \multicolumn{2}{|l|}{ Denmark } \\
\hline \multicolumn{2}{|l|}{ 1970:1 } \\
\hline 1971:2 & May: Bundesbank buy $\$$ \\
\hline 1973:3 & (June: Dannish krone devaluated by $6 \%$ ) \\
\hline $1976: 3$ & $\begin{array}{l}\text { Bundesbank intervention in favour of the } \\
\text { smaller non-German participants in the snake }\end{array}$ \\
\hline \multicolumn{2}{|r|}{ 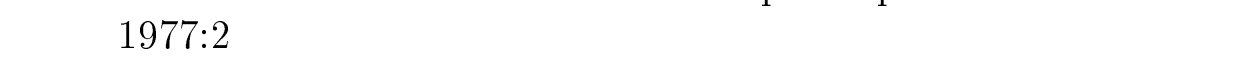 } \\
\hline 1979:4 & 30 Nov: Dannish krone devaluated by $4.8 \%$ \\
\hline 1982:1 & 22 Feb: Dannish krone devaluated by $3 \%$ \\
\hline 1992:3 & EMS tensions \\
\hline 1993:3 & $\begin{array}{l}29 \text { July: Dannish krone falls below their } \\
\text { EMS floor; widening of the fluctuations margins } \\
\text { to } \pm 15 \%\end{array}$ \\
\hline 1995:1 & New EMS tensions \\
\hline
\end{tabular}

Finland

\begin{tabular}{ll}
\hline $1970: 3$ & \\
$1973: 1$ & floating of the $\$ ;$ 19 March: DM revaluated by $3 \% ;$ \\
$1973: 3$ & problems derived from the oil crisis \\
$1977: 2$ & \\
$1982: 4$ & tensions in some EMS currencies \\
$1991: 4$ & 15 Nov: Finnish markka devaluated by 12.3\% \\
$1992: 3$ & $\begin{array}{l}\text { EMS tensions: 8 Sept. Finnish markka has to } \\
\text { abandon its ECU peg }\end{array}$ \\
$1993: 1$ & $\begin{array}{l}\text { Renewed EMS tensions } \\
\text { widening of the fluctuations margins to } \pm 15 \%\end{array}$ \\
\hline \hline
\end{tabular}


Continuation Table C

\begin{tabular}{|c|c|}
\hline $\begin{array}{l}\text { Beginning of the } \\
\text { Currency Crisis }\end{array}$ & Associated Event (if applicable) \\
\hline
\end{tabular}

\begin{tabular}{|c|c|}
\hline France & \\
\hline 1971:3 & August: US suspension of the link $\$ /$ gold \\
\hline 1973:3 & problems derived from the oil shock \\
\hline 1976:1 & $\begin{array}{l}\text { France withdraws from the snake; Bundesbank } \\
\text { interventions }\end{array}$ \\
\hline 1978:1 & Appreciation of the DM by $7 \%$ \\
\hline 1978:4 & 17 Oct. DM revaluated by $4 \%$ \\
\hline 1981:4 & Oct. French franc devaluated by $3 \%$ \\
\hline 1982:3 & \\
\hline 1983:2 & \\
\hline 1992:3 & EMS tensions \\
\hline
\end{tabular}

\section{Greece}

1971:3

August: US suspension of the link \$/gold

1973:2

DM revaluated by $5.5 \%$ (tensions derived from the

1974:3

floating of the $\$$ the previous quarter)

1980:1

1982:2

DM revaluated by $4.25 \%$

1983:1

DM revaluated by $5.5 \%$

1985:4

\section{Ireland}

1970:2

1972:2

May: joins the snake; June: witdraws

1973:1

1973:3

floating of the $\$$ creates tensions in the snake

1976:2

1976:4

1986:3

problems coming from the oil shock

1992:3

4 August: Irish punt devaluated by $8 \%$

EMS tensions 
Continuation Table C

\begin{tabular}{|c|c|}
\hline $\begin{array}{l}\text { Beginning of the } \\
\text { Currency Crisis }\end{array}$ & Associated Event (if applicable) \\
\hline \multicolumn{2}{|l|}{ Italy } \\
\hline \multicolumn{2}{|l|}{ 1970:2 } \\
\hline 1973:2 & DM revaluated by $5.5 \%$ \\
\hline \multicolumn{2}{|l|}{ 1974:4 } \\
\hline 1976:1 & tensions in the snake \\
\hline 1992:3 & $\begin{array}{l}\text { EMS tensions: } 10-11 \text { Sept. Italian lira falls below its } \\
\text { EMS floor. Massive interventions by Banca d'Italia } \\
\text { and Bundesbank; } 14 \text { Sept. Italian lira devaluated by } \\
3.5 \% \text {; } 16 \text { Sept. suspension of Italian lira from } \\
\text { participation }\end{array}$ \\
\hline 1995:1 & Renewed problems in the EMS \\
\hline \multicolumn{2}{|l|}{ Japan } \\
\hline \multicolumn{2}{|l|}{$1979: 1$} \\
\hline \multicolumn{2}{|l|}{ 1979:4 } \\
\hline \multicolumn{2}{|l|}{ 1989:2 } \\
\hline \multicolumn{2}{|l|}{ 1991:1 } \\
\hline \multicolumn{2}{|l|}{ 1995:3 } \\
\hline \multicolumn{2}{|l|}{ 1997:1 } \\
\hline \multicolumn{2}{|l|}{ Netherlands } \\
\hline \multicolumn{2}{|l|}{$1970: 2$} \\
\hline 1973:2 & DM revaluated by $5.5 \%$ \\
\hline 1978:3 & $\begin{array}{l}\text { Interventions to support the } \$ \text { that translates into } \\
\text { ulterior revaluations of the DM }\end{array}$ \\
\hline \multicolumn{2}{|l|}{$1980: 3$} \\
\hline 1992:3 & EMS tensions \\
\hline
\end{tabular}




\section{Continuation Table C}

\begin{tabular}{|c|c|}
\hline $\begin{array}{l}\text { Beginning of the } \\
\text { Currency Crisis }\end{array}$ & Associated Event (if applicable) \\
\hline \multicolumn{2}{|l|}{ New Zealand } \\
\hline $1975: 3$ & \multirow{9}{*}{ IMF legalize the non-system } \\
\hline $1976: 2$ & \\
\hline 1980:1 & \\
\hline 1980:3 & \\
\hline 1982:1 & \\
\hline 1984:3 & \\
\hline 1985:1 & \\
\hline 1986:3 & \\
\hline 1988:3 & \\
\hline \multicolumn{2}{|l|}{ Norway } \\
\hline 1970:2 & \\
\hline 1973:1 & End of Bretton Woods; DM revaluated by $3 \%$ \\
\hline $1973: 3$ & $\begin{array}{l}\text { DM revaluated by } 5.5 \% \text {; Norwegian krone } \\
\text { devaluated by } 13 \%\end{array}$ \\
\hline \multicolumn{2}{|l|}{$1977: 4$} \\
\hline \multicolumn{2}{|l|}{ 1982:3 } \\
\hline \multicolumn{2}{|l|}{ 1986:2 } \\
\hline 1992:3 & $\begin{array}{l}\text { EMS tensions (10 Dec. Norway discontinues the } \\
\text { on the ECU and its currency is allowed to float }\end{array}$ \\
\hline \multicolumn{2}{|l|}{ Portugal } \\
\hline \multicolumn{2}{|l|}{$1976: 2$} \\
\hline \multirow{2}{*}{\multicolumn{2}{|c|}{$\begin{array}{l}1977: 1 \\
1978: 2\end{array}$}} \\
\hline & \\
\hline 1978:4 & 17 Oct. DM revaluated by $4 \%$ \\
\hline \multicolumn{2}{|l|}{ 1982:3 } \\
\hline 1992:3 & $\begin{array}{l}\text { EMS tensions: } 22 \text { Nov. Porugues escudo devaluated } \\
\text { by } 6 \%\end{array}$ \\
\hline
\end{tabular}




\section{Continuation Table C}

\begin{tabular}{|c|c|}
\hline $\begin{array}{l}\text { Beginning of the } \\
\text { Currency Crisis }\end{array}$ & Associated Event (if applicable) \\
\hline \multicolumn{2}{|l|}{ Spain } \\
\hline \multicolumn{2}{|l|}{ 1970:2 } \\
\hline 1973:1 & $\begin{array}{l}\text { March: end of Bretton Woods; } \\
\text { 19March: DM revaluated by } 3 \%\end{array}$ \\
\hline 1973:3 & June: DM revaluated by $5.5 \%$ \\
\hline 1976:1 & 9 Feb. Spanish peseta devaluated by $13 \%$ \\
\hline 1977:3 & $\begin{array}{l}\text { July: Spanish peseta is allowed to float to a } \\
20 \% \text { depreciation }\end{array}$ \\
\hline 1983:1 & 21 March: DM revaluated by $5.5 \%$ \\
\hline 1992:3 & $\begin{array}{l}\text { EMS tensions: } 16 \text { Sept. Spanish peseta devaluated } \\
\text { by } 5 \% ; 22 \text { Nov. new devaluation by } 6 \%\end{array}$ \\
\hline 1993:3 & (13 May: Spanish peseta devaluated by $8 \%$ ) \\
\hline \multicolumn{2}{|l|}{ Sweden } \\
\hline \multicolumn{2}{|l|}{ 1970:1 } \\
\hline 1973:1 & $\begin{array}{l}\text { March: end of Bretton Woods; } \\
19 \text { March: DM revaluated by } 3 \% \text { and Sweden becomes } \\
\text { associated (of the snake) }\end{array}$ \\
\hline \multicolumn{2}{|l|}{ 1977:3 } \\
\hline 1981:4 & Oct. DM revaluated by $5.5 \%$ \\
\hline 1982:4 & 2 Oct. Sweden devaluated by $15.9 \%$ \\
\hline 1992:3 & $\begin{array}{l}\text { EMS tensions: } 16 \text { Sept. Sweden raise its marginal } \\
\text { lending rate; } 19 \text { Nov. Swedish krone breaks its link }\end{array}$ \\
\hline \multicolumn{2}{|l|}{ Switzerland } \\
\hline \multicolumn{2}{|l|}{ 1970:1 } \\
\hline \multirow{2}{*}{\multicolumn{2}{|c|}{$\begin{array}{l}1970: 3 \\
1971: 1\end{array}$}} \\
\hline & \\
\hline 1972:4 & Early 73 : Swish franc floats against the $\$$ \\
\hline \multicolumn{2}{|l|}{ 1973:3 } \\
\hline 1978:4 & 17 Oct. DM revaluated by $4 \%$; interventions to support the $\$$ \\
\hline 1981:1 & Bundesbank tights monetary policy \\
\hline 1982:2 & 14 June: DM revaluated by $4.25 \%$ \\
\hline 1992:3 & EMS tensions \\
\hline
\end{tabular}


Continuation Table C

\begin{tabular}{|c|c|}
\hline $\begin{array}{l}\text { Beginning of the } \\
\text { Currency Crisis }\end{array}$ & Associated Event (if applicable) \\
\hline \multicolumn{2}{|l|}{ U.K. } \\
\hline 1970:2 & \\
\hline 1972:2 & $\begin{array}{l}1 \text { May: UK joins snake } \\
23 \text { June: UK withdraws }\end{array}$ \\
\hline 1973:3 & \\
\hline 1976:2 & \\
\hline 1976:4 & \\
\hline 1981:4 & $\begin{array}{l}\text { Oct. DM revaluated by } 5.5 \% \\
\text { (UK joined EMS in July' } 79 \text { ) }\end{array}$ \\
\hline 1983:1 & 21 March: DM revaluated by $5.5 \%$ \\
\hline 1986:1 & \\
\hline 1986:3 & Depreciation $\$$ \\
\hline 1992:3 & $\begin{array}{l}\text { EMS tensions: } 16 \text { Sept. heavy interventions fail to lift sterling } \\
\text { from its EMS floor. Temporarily suspension of the sterling } \\
\text { participation }\end{array}$ \\
\hline \multicolumn{2}{|l|}{ U.S.A. } \\
\hline 1970:2 & \\
\hline 1971:3 & August: US suspension of the link $\$ /$ gold \\
\hline 1973:1 & $\begin{array}{l}\text { March: end of Bretton Woods; } \\
19 \text { March: DM revaluated by } 3 \% \text { and Sweden becomes } \\
\text { associated (of the snake) }\end{array}$ \\
\hline 1979:3 & Sept. Bundesbank intervenes to support the $\$$ \\
\hline 1980:4 & \\
\hline 1985:4 & Starts depreciation of the $\$$ (after a period of appreciation) \\
\hline 1987:1 & Feb. Louvre Accord: G5 intervens buying $\$$ \\
\hline 1992:3 & weakness of the $\$$ \\
\hline
\end{tabular}


Table D: Maximum Likelihood Estimates

\begin{tabular}{lccc}
\hline \hline Parameters & Estimates & Std. error & Expected sign \\
\hline \hline & & & \\
Independent Variables & & & - \\
\hline Growth & -0.07 & 0.08 & + \\
Inflation & 0.10 & 0.08 & + \\
Unemployment & 0.01 & 0.02 & - \\
Export Growth & $-0.04^{* *}$ & 0.02 & + \\
Import Growth & $0.03^{* *}$ & 0.02 & - \\
Openness & $-0.01^{* *}$ & 0.01 & + \\
REER & $0.02^{*}$ & 0.01 & + \\
Deposits/GDP (rate of growth) & $-0.05^{*}$ & 0.03 & + \\
Claims on Government/GDP & $0.01^{* *}$ & 0.01 & - \\
Portfolio Investment/GDP & $0.07^{* * *}$ & 0.03 & + \\
FDI/GDP & -0.01 & 0.12 & \\
& & & \\
\hline \hline
\end{tabular}

${ }^{*},{ }^{* *}$ and ${ }^{* * *}$ indicates significance at $10 \%, 5 \%$ and $1 \%$ respectevely. 
Table E: Maximum Likelihood Estimates

\begin{tabular}{lccc}
\hline \hline Parameters & Estimates & Std. error & Expected sign \\
\hline \hline & & & \\
Independent Variables & & & - \\
\hline Growth & -0.07 & 0.08 & + \\
Inflation & 0.80 & 0.08 & + \\
Unemployment & 0.01 & 0.02 & - \\
Export Growth & $-0.04^{* * *}$ & 0.02 & + \\
Import Growth & $0.03^{* * *}$ & 0.01 & - \\
Openness & $-0.01^{* *}$ & 0.01 & - \\
REER (deviation from trend) & $-0.08^{* * *}$ & 0.03 & + \\
Deposits/GDP (rate of growth) & $-0.05^{* *}$ & 0.03 & + \\
Domestic Credit/GDP & -0.002 & 0.005 & - \\
Portfolio Investment/GDP & $0.06^{* * *}$ & 0.03 & \\
FDI/GDP & 0.002 & 0.13 & \\
& & & \\
\hline \hline
\end{tabular}

${ }^{*},{ }^{* *}$ and ${ }^{* * *}$ indicates significance at $10 \%, 5 \%$ and $1 \%$ respectevely. 


\section{References}

Agenor, P. R., Bhandari, J. S. and Flood, R. P. (1992), Speculative Attacks and Models of Balnce of Payments Crises, IMF Staff Papers 39, 357-394.

Blanco, H. and Garber, P. M. (1986), Recurrent Devaluation and Speculative Attacks on the Mexican Peso, Journal of Political Economy 94, 148-166.

Cox, D. R. (1972), Regression Models and Life-tables, J. R. Statist. Soc. B 34, 187-220.

Dornbusch, R., Goldfajn, I. and Valdés, R. O. (1995), Currency Crises and Collapses, Brooking Papers on Economic Activity 2, 219-295.

Eichengreen, B., Rose, A. and Wyplosz, C. (1994), Speculative Attacks on Pegged Exchange Rates: An Empirical Exploration with Special Reference to the European Monetary System, NEBER Working Paper Series, working paper 4898.

Eichengreen, B., Rose, A. and Wyplosz, C. (1995), Exchange Market Mayhem: The Antecedents and Aftermath of Speculative Attacks, Economic Policy 21, 249-312.

Eichengreen, B., Rose, A. and Wyplosz, C. (1996), Contagious Currency Crises: First Test, Scandinavian Journal of Economics 98(4), 463484.

Eichengreen, B., Rose, A. and Wyplosz, C. (1997), Contagious Currency Crises, Mimeo, working paper .

Flood, R. and Garber, P. (1984), Collapsing Exchange-Rate Regimes: Some Linear Examples, Journal of International Economics 17, 1-13.

Frankel, J. and Rose, A. (1996), Currency Crashes in Emerging Markets: An Empirical Treatment, Board of Governors of the Federal Reseve System. International Finance Discussion Papers, working paper 534.

Garber, P. M. and Svensoon, L. E. O. (1994), The Operation and Collapse of Fixed Exchange Rate Regimes, NBER Working Paper Series, working paper 4971. 
Goldstein, M. (1996), Presumptive Indicators/Early Warning Signals of Vulnerability to Financial Crises in Emerging Markets Economies, Mimeo, working paper .

Jeanne, O. and Masson, P. (1997), Was the French Franc Crisis a Sunspot Equilibrium?, International Monetary Fund, Mimeo, working paper .

Kaminsky, G. L., Lizondo, S. and Reinhart, C. M. (1998), Leading Indicators of Currency Crises, IMF Staff Papers.

Kiefer, D. (1988), Economic Duration Data and Hazard Functions, Journal of Economic Literature XXVI, 646-679.

Klein, M. W. and Marion, N. P. (1994), Explaining the Duration of Exchange Rate Pegs, NEBER Working Paper Series, working paper 4651.

Krugman, P. (1979), A Model of Balance of Payments Crises, Journal of Money, Credit and Banking 11, 311-325.

Krugman, P. (1996), Are Currency Crises Self-fulfilling?, NEBER Macroeconomics Annual, working paper .

Kumar, M. S., Moorthy, U. and Perraudin, W. (1998), Financial Crises: Contagion and Market Volatility, A CEPR/World Bank Conference, Mimeo, working paper .

Lancaster, T. (1990), The Econometric Analysis of Transition Data, Econometrics Society Monographs. Cambridge University Press.

Milesi-Ferreti, G. M. and Razin, A. (1998), Current Account Sustanability, Whasington: Institute for International Economics, Mimeo, working paper .

Moreno, R. (1995), Macroeconomic Behavior During Periods of Speculative Pressure or Realignment: Evidence from Pacific Basin Economies, Economic Review, Federal Reserve Bank of San Francisco 3, 3-16.

Narendranathan, W. and Stewart, M. B. (1993), Modelling the Probability of Leaving Unemployment: Competing Risk Models with Flexible Base-line Hazards, Applied Statistics 42(1), 63-83. 
Sachs, J., Tornell, A. and Velasco, A. (1996), Financial Crises in Emerging Markets: The Lessons from 1995, NBER Working Paper Series, working paper 3676 .

Wyplosz, C. (1986), Capital Controls and Balance of Payments Crises, Journal of International Money and Finance 5, 167-179. 


\section{CENTRE FOR ECONOMIC PERFORMANCE Recent Discussion Papers}

\begin{tabular}{|c|c|c|}
\hline 486 & D. Sturm & Product Standards, Trade Disputes and Protectionism \\
\hline 485 & $\begin{array}{l}\text { G. Duranton } \\
\text { V. Monastiriotis }\end{array}$ & $\begin{array}{l}\text { Mind the Gaps: The Evolution of Regional Inequalities in } \\
\text { the UK 1982-1997 }\end{array}$ \\
\hline 484 & $\begin{array}{l}\text { H. G. Overman } \\
\text { Y. Ioannides }\end{array}$ & Zipfs Law for Cities: An Empirical Examination \\
\hline 483 & $\begin{array}{l}\text { H. G. Overman } \\
\text { Y. Ioannides }\end{array}$ & Cross Sectional Evolution of the US City Size Distribution \\
\hline 482 & $\begin{array}{l}\text { Y. Ioannides } \\
\text { H. G. Overman }\end{array}$ & Spatial Evolution of the US Urban System \\
\hline 481 & H. G. Overman & Neighbourhood Effects in Small Neighbourhoods \\
\hline 480 & S. Gomulka & $\begin{array}{l}\text { Pension Problems and Reforms in the Czech Republic, } \\
\text { Hungary, Poland and Romania }\end{array}$ \\
\hline 479 & $\begin{array}{l}\text { S. Nickell } \\
\text { T. Jones } \\
\text { G. Quintini }\end{array}$ & A Picture of the Job Insecurity Facing British Men \\
\hline 478 & C. Dougherty & $\begin{array}{l}\text { Numeracy, Literacy and Earnings: Evidence from the } \\
\text { National Longitudinal Survey of Youth }\end{array}$ \\
\hline 477 & P. Willman & $\begin{array}{l}\text { The Viability of Trade Union Organisation: A Bargaining } \\
\text { Unit Analysis }\end{array}$ \\
\hline 476 & $\begin{array}{l}\text { D. Marsden } \\
\text { S. French } \\
\text { K. Kubo }\end{array}$ & $\begin{array}{l}\text { Why Does Performance Pay De-Motivate? Financial } \\
\text { Incentives versus Performance Appraisal }\end{array}$ \\
\hline 475 & S. Gomulka & $\begin{array}{l}\text { Macroeconomic Policies and Achievements in Transition } \\
\text { Economies, 1989-1999 }\end{array}$ \\
\hline 474 & $\begin{array}{l}\text { S. Burgess } \\
\text { H. Turon }\end{array}$ & $\begin{array}{l}\text { Unemployment Dynamics, Duration and Equilbirum: } \\
\text { Evidence from Britain }\end{array}$ \\
\hline 473 & $\begin{array}{l}\text { D. Robertson } \\
\text { J. Symons }\end{array}$ & $\begin{array}{l}\text { Factor Residuals in SUR Regressions: Estimating Panels } \\
\text { Allowing for Cross Sectional Correlation }\end{array}$ \\
\hline 472 & $\begin{array}{l}\text { B. Bell } \\
\text { S. Nickell } \\
\text { G. Quintini }\end{array}$ & Wage Equations, Wage Curves and All That \\
\hline
\end{tabular}


$471 \quad$ M. Dabrowski

S. Gomulka

J. Rostowski

$470 \quad$ B. Petrongolo

C. A. Pissarides

469 W. H. Buiter

468 A. S. Litwin

467 P. B. Kenen

466 S. Gomulka J. Lane

465 F. Green

S. McIntosh

464 J. P. Neary

463 M. Güell

462 W. H. Buiter

461 M. Güell

460 P. Ramezzana

459 H. Lehmann

J. Wadsworth

$458 \quad$ R. Griffith

S. Redding

J. Van Reenen

457 J. Swaffield
Whence Reform? A Critique of the Stiglitz Perspective

Looking Into the Black Box: A Survey of the Matching Function

Monetary Misconceptions

Trade Unions and Industrial Injury in Great Britain

Currency Areas, Policy Domains and the

Institutionalization of Fixed Exchange Rates

A Simple Model of the Transformational Recession Under a Limited Mobility Constraint

Working on the Chain Gang? An Examination of Rising Effort Levels in Europe in the 1990s

R\&D in Developing Countries: What Should Governments Do?

Employment Protection and Unemployment in an Efficiency Wage Model

Optimal Currency Areas: Why Does the Exchange Rate Regime Matter?

Fixed-Term Contracts and Unemployment: An Efficiency Wage Analysis

Per Capita Income, Demand for Variety, and International Trade: Linder Reconsidered

Tenures that Shook the World: Worker Turnover in Russia, Poland and Britain

Mapping the Two Faces of R\&D: Productivity Growth in a Panel of OECD Industries

Gender, Motivation, Experience and Wages

To order a discussion paper, please contact the Publications Unit Tel 02079557673 Fax 02079557671 Email info@cep.lse.ac.uk Web site http://cep.lse.ac.uk 